\title{
INSTITUTIONAL POLYCENTRISM, ENTREPRENEURS' SOCIAL NETWORKS, AND NEW VENTURE GROWTH
}

\author{
BAT BATJARGAL \\ Harvard University and Peking University \\ MICHAEL A. HITT \\ Texas A\&M University \\ ANNE S. TSUI \\ Fudan University, Shanghai Jiao Tong University, \\ Peking University, and Arizona State University \\ JEAN-LUC ARREGLE \\ EM Lyon Business School \\ JUSTIN W. WEBB \\ Oklahoma State University \\ TOYAH L. MILLER \\ Indiana University
}

\begin{abstract}
What is the interrelationship among formal institutions, social networks, and new venture growth? Drawing on the theory of institutional polycentrism and social network theory, we examine this question using data on 637 entrepreneurs from four different countries. We find the confluence of weak and inefficient formal institutions to be associated with a larger number of structural holes in entrepreneurial social networks. While the effect of this institutional order on the revenue growth of new ventures is negative, a network's structural holes have a positive effect on revenue growth. Furthermore, the positive effect of structural holes on revenue growth is stronger in an environment with a more adverse institutional order (i.e., weaker and more inefficient institutions). The contributions and implications of these findings are discussed.
\end{abstract}

Entrepreneurial ventures contribute to the economic development of nations; therefore, understanding the influences on the creation and growth

Please address correspondence regarding this article to Anne S. Tsui. We thank Howard Aldrich, Robert Barro, Candida Brush, Phillip Kim, Bradley Kirkman, Jun Liu, Rachel McCleary, Andrei Shleifer, reviewers of the 2009 Academy of Management Conference, and participants of seminars at Harvard Business School, Harvard University's Davis Center and Fairbank Center, Fudan University, INSEAD, IESE, Nanyang Technological University, Singapore Management University, University of Reading, and Rice University for comments and suggestions. We are grateful to our research assistants, who conducted interviews. This project was partially funded by a grant to Anne Tsui from the National Natural Science Foundation of China (\#71032001). of these ventures is of both theoretical and practical importance (Baumol \& Strom, 2007). We know from extant research that entrepreneurs often cultivate and use social networks to access resources (e.g., capital, knowledge, supplies) that facilitate new venture growth (Eisenhardt \& Schoonhoven, 1996; Granovetter, 1995; Kim \& Aldrich, 2005; Stam \& Elfring, 2008; Stuart \& Sorenson, 2007). Prior research suggests that the use of social networks is influenced by institutional contexts (e.g., Brass, Galaskiewicz, Greve, \& Tsai, 2004). Institutions establish the rules of the game for entrepreneurial activities and thereby influence both the nature and outcomes of entrepreneurs' social networks (Baumol, 1990; Boettke \& Coyne, 2009; Djankov, La Porta, Lopez de Silanes, \& Shleifer, 2002; Hwang \& Powell, 2005; Owen-Smith \& Pow-

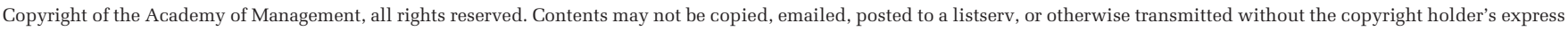
written permission. Users may print, download, or email articles for individual use only. 
ell, 2008). The purpose of this research is to examine how formal institutions affect the development and use of entrepreneurs' social networks and new venture growth. We employ the theory of institutional polycentrism, which suggests that institutions originate from multiple (poly) rule-setting centers such as governments, associations, and communities (Ostrom, 2010).

Although there has been a considerable amount of research on the effects of specific institutions (e.g., political risk) on particular managerial decisions, institutions are complex and multifaceted (Greenwood, Raynard, Kodeih, Micelotta, \& Lounsbury, 2011; Kogut \& Ragin, 2006) and their effects on firm actions are interdependent (Delmas \& Toffel, 2008; Hitt, Ahlstrom, Dacin, Levitas, \& Svobodina, 2004). The theory of institutional polycentrism postulates that institutional environments are characterized by multiplicity, which is defined as the confluence of different types of interrelated institutions (Ostrom, 2005a). The confluence of multiple institutions is theorized to have qualitatively different effects on outcomes than a single institution or several institutions, because the confluence is characterized by dynamic interaction, mutual reinforcement, and a cointegrated and nonseparable nature of diverse institutional rules and norms within the entire institutional order (Ostrom, 2005a, 2005b; Ostrom, Schroeder, \& Wynne, 1993). On the contrary, a single institution or several institutions may not affect entrepreneurial growth directly, and therefore, are alone less relevant for new ventures at early stages of development (Tzeng, Beamish, \& Chen, 2011). The confluence of political, regulatory, and economic institutions affects outcomes in interdependent and composite manners partly because of their common historical, geographic, and cultural foundations (Acemoglu, Johnson, \& Robinson, 2005; Amable, 2003; Greif \& Tabellini, 2010; Hall \& Soskice, 2001; Hall \& Thelen, 2009; Holmes, Miller, Hitt, \& Salmador, 2013; Ostrom, 1986, 2005a, 2010; Sobel \& Coyne, 2011). In contrast to previous research that mainly explored the influence of a single institution or regulatory, normative, and cognitive pillars of national institutions separately (Busenitz, Gomez, \& Spencer, 2000; Fogel, Hawk, Morck, \& Yeung, 2006), this study examines the effects of the confluence of multiple (political, regulatory, and economic) institutions on entrepreneurs' networks and new venture growth. Figure 1 presents our theoretical model.

The theory of institutional polycentrism further suggests that the confluence of weak and inefficient institutions motivates social actors to use their networks as substitutes for the lack of institutional support, because loose-knit networks help them to acquire resources from informal resource holders who partially operate outside formal institutional arrangements (Ostrom et al., 1993; Ostrom \& Ahn, 2009; Webb, Tihanyi, Ireland, \& Sirmon, 2009). ${ }^{1}$ In

\footnotetext{
${ }^{1}$ From the perspective of institutional polycentrism, a weak institution involves one or more institutional rules that are unable to achieve their intended goals and objectives (e.g., weak political and economic institutions), whereas an inefficient institution is an interventionist institution that increases the transaction costs of eco-
}

FIGURE 1

Model: Institutional Polycentrism, Network Structural Holes, and New Venture Growth

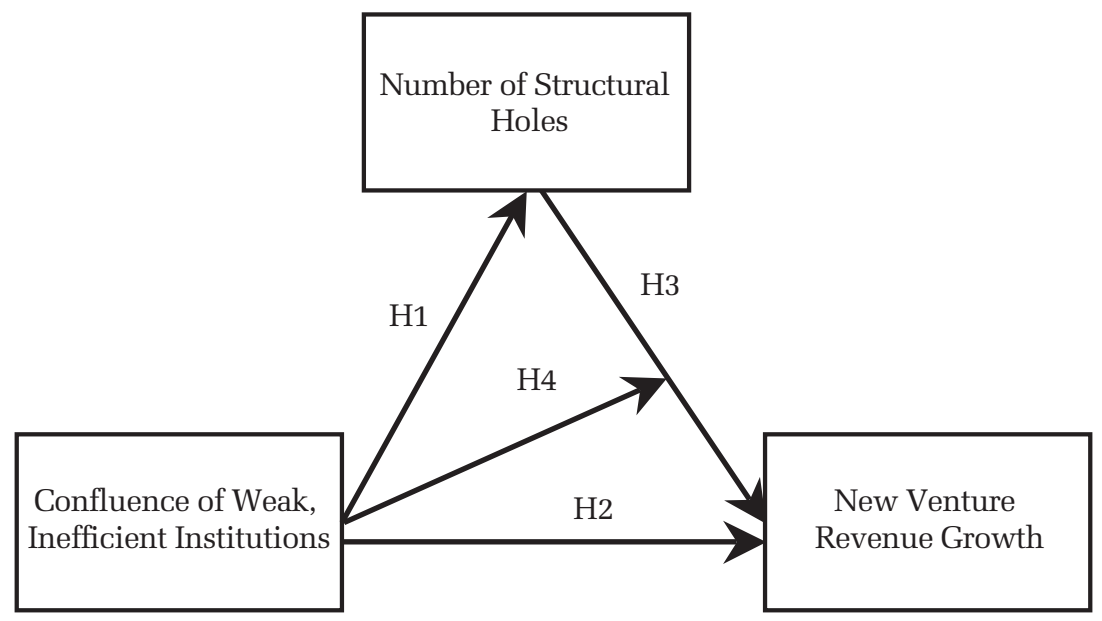


this way, the confluence of weak and inefficient institutions and social networks affects outcomes including entrepreneurial growth in synergistic ways (Ostrom, 2005b). Therefore, we focus on two concepts of the theory of institutional polycentrism to explain entrepreneurs' networks and venture growth: multiplicity of different types of institutions (e.g., political, regulatory, and economic) and institutional substitution. We posit that institutional multiplicity characterizes the institutional environment that exerts influence on entrepreneurial networks and ventures, whereas institutional substitution is a mechanism through which entrepreneurs' networks compensate for weak and inefficient institutions, thus enhancing their effect on new venture growth.

Extending the theory of institutional polycentrism and integrating it with social network theory, we examine the following four questions: (a) Does the confluence of weak and inefficient political, regulatory, and economic institutions affect the development of a network's structural holes (the absence of a link between two contacts who are both linked to an actor)? (b) Does the confluence of weak and inefficient political, regulatory, and economic institutions affect new venture growth? (c) Do structural holes in entrepreneurs' networks affect new venture growth? (d) Does the confluence of weak and inefficient political, regulatory, and economic institutions moderate the relationship between network's structural holes and new venture growth? We explore these questions using structured interview data from 637 new venture firms founded in one of four nations (China, France, Russia, and the United States) that display varying and unique institutional orders (World Bank, 2010).

A number of contributions flow from this research. First, by employing the relatively new concepts institutional multiplicity and institutional substitution to explain entrepreneurs' networks and growth of new ventures, we integrate and systematize disparate ideas on polycentric institutions to develop a cohesive theory of institutional polycentrism, which represents a contribution to institutional theory and research. Second, this study contributes to institution-based comparative research on entrepreneurship, further contributing to understanding of new venture growth by using an integrated perspective on institutional polycen-

nomic activities (e.g., inefficient regulatory institutions) (Ostrom et al., 1993; Shleifer, 2005). trism and social networks (Cumming, Sapienza, Siegel, \& Wright, 2009; Lerner \& Schoar, 2010). As a third contribution, our study "opens the door" to the possibilities associated with studying entrepreneurship within an informal economy context characterized by illegality yet legitimacy (Webb et al., 2009). Finally, structural holes in entrepreneurs' networks enable them to access informal resource holders and their resources when the formal institutional order is adverse for entrepreneurs. As such, this research provides a contribution to knowledge on the contingent value of networks and how entrepreneurs manage network resources (Brass et al., 2004; Burt, 1992; Xiao \& Tsui, 2007).

\section{THEORETICAL FRAMEWORK AND HYPOTHESES}

\section{Institutional Polycentrism Theory}

The notion of polycentricity refers to a spontaneous order in which multiple and independent decision-making centers and actors make mutual adjustments for ordering their relations within a general framework of rules and norms (Ostrom, 1999a, 1999b; Polanyi, 1951). In this sense, polycentricity is the extent to which the adjustment of each actor in the order is related in a certain manner to the adjustment of every one of these actors to each of the others. The totality of these spontaneous interactions and adjustments represents a polycentric order (Aligica \& Tarko, 2012).

The concept of institutional polycentricity denotes spontaneous interactions of multiple institutional rules and norms, and mutual adjustments among institutional actors. Social actors, including organizations and individuals, pursue their goals in polycentric institutional settings where they comply with multiple governance rules at different levels and scales embedded in local knowledge and particular settings (Ostrom, 1990). Therefore, polycentric institutional order is a complex system of governance in which authorities from overlapping jurisdictions (or "centers" of authority) interact to determine the conditions and constraints under which units of governance, such as organizations and individuals, act legitimately (McGinnis, 2011).

Institutional polycentrism theory defines polycentric institutions as multiple, configurational, and context-specific institutional rules and norms that originate from, are situated in, and are enforced by numerous decision-making power cen- 
ters. Therefore, polycentric institutional order is a self-coordinating spontaneous system that results from the interplay of multiple, complex, recombined, and particular context-embedded rules and norms, and the interchanges among numerous interdependent institutional actors (Hayek, 1973; Ostrom, 1999a; Polanyi, 1951). Thus, the main theoretical postulates of institutional polycentrism are institutional multiplicity, institutional configuration, and institutional context specificity (Greif, 2006; Hall \& Thelen, 2009; Ostrom, 1986, 2005a, 2010).

In this study, we examine the roles of institutional multiplicity and institutional substitution, two key dimensions of institutional polycentrism, in the development of entrepreneurs' networks and venture growth. Institutional multiplicity as a confluence of institutions is defined as dynamic interplay, mutual reinforcement, and cointegration of diverse rules and norms in which the effect of change in one rule and norm or a set of rules and norms is contingent upon other rules and norms in use (Ostrom, 2011). Institutional substitution is a process in which weak (e.g., nonenforced) and inefficient rules lead to the rise of alternative sets of rules, norms, and networks that compensate for their lack of influence and usefulness (Crouch, 2005; Hall \& Soskice, 2001; North, 1990, 2005; Ostrom et al., 1993). Thus, substitution is a process in which one set of formal institutions and informal networks is used to replace or overcome the debilitating effects of multiple weak and inefficient institutions (Deeg, 2005; Hall \& Soskice, 2001).

\section{Confluence of Weak and Inefficient Institutions and Networks' Structural Holes}

The combination of weak and inefficient national-level institutions enhances the importance of informal norms and networks (Holmes et al., 2013; Ostrom, 2005a, 2005b). When national institutions are weak and inefficient, many formal and informal institutions must be considered by managers, and such a context generates uncertainty and ambiguity as to which is the most relevant institution or set of institutions for a given situation (Heberer, 2003). The authority for rule making and enforcement becomes more diffused and sometimes difficult to identify. These conditions create special challenges for entrepreneurs with new ventures, who need to identify what is needed to achieve legitimacy and to access resources for survival and growth. However, when national formal institutions are stronger and more efficient, they often take precedence over other lower-level institutions and are more likely to be congruent with informal institutions (e.g., social norms), thereby creating an environment of lower uncertainty and ambiguity (Holmes et al., 2013).

The confluence of multiple weak and inefficient institutions creates an institutional order in which negative change in one rule or sets of rules triggers negative changes in other rules in use, because of the cointegrated and interdependent nature of institutions (Ostrom, 2005a; Sobel \& Coyne, 2011). This catalytic process results in negative reinforcement among the institutions (Schneider \& Karcher, 2010; Wilson \& Herzberg, 2000), increased conflicts among various institutions (Hancke, 2010; Pache \& Santos, 2010; Seo \& Creed, 2002), and institutional deterioration, leading weak and inefficient institutions to become even weaker and more inefficient (Acemoglu et al., 2005; North \& Shirley, 2008). These destructive interdependent processes make the entire institutional order adverse for entrepreneurs, motivating them to build diverse networks rich in structural holes as informal substitute channels for resource acquisition (Batjargal, 2006; Kharkhordin \& Gerber, 1994; Sedaitis, 1998; Webb et al., 2009).

Networks rich in structural holes facilitate venture growth because entrepreneurs use them to gain access to nonredundant information and resources and to obtain social support (Batjargal, 2007a; Burt, 1992; Stam \& Elfring, 2008). Additionally, the positive effect of a network's structural holes on venture growth is stronger when the confluence of weak and inefficient institutions creates an adverse institutional order, forcing entrepreneurs to reach out to informal resource holders who operate largely beyond their formal institutional arrangements (Nee, 2005; Ostrom, 2005b; Ostrom \& Ahn, 2009).

Each type of weak and inefficient institution generates forms of institutional uncertainty and ambiguity, such as uncertainty regarding access to financial resources or as to ability to transact efficiently (Feldmann, 2007; Sobel, Clark, \& Lee, 2007). However, when one set of institutions is weak, but other, relatively strong institutions exist, social actors rely on the stronger institutions to mitigate the negative consequences of the dysfunctional ones (Herrmann, 2008). For example, when labor market institutions are weak but government employment policies are relatively strong, then these policies offset the negative externalities of the dysfunctional labor market institutions (Wulfgramm, 2011). In this way, the negative implications of one 
type of weak and inefficient institution are less detrimental for entrepreneurs if there are other stronger and more efficient institutions that compensate for the deficiencies (Heberer, 2003). However, when there is a confluence of different types of weak and inefficient formal institutions, the negative synergy makes the entire formal institutional environment highly uncertain for entrepreneurs, because there is little or no formal institutional support of which they can be assured (Boettke, Coyne, \& Leeson, 2008; Fogel et al., 2006; Ovaska \& Sobel, 2005; Wilson \& Herzberg, 2000). The cumulative effects of the negative synergy among weak and inefficient institutions increase the strategic value of diverse entrepreneurial networks (Batjargal, 2000, 2003a, 2007a; Heberer, 2003; Sedaitis, 1998; Xin \& Pearce, 1996).

Political institutional systems that lack democratic checks and balances tend to be weak and unstable, resulting in distrust among social actors, including entrepreneurs in such institutions (Ledeneva, 1998). These political institutions often disadvantage those groups that are not members of the ruling political parties and clans (Tsai, 2007). The mistrust of public institutions results in the development of diverse private networks that serve as alternative channels for information exchange, resources, and social support (Tsai, 2002). The real and perceived institutional discrimination motivates entrepreneurs to build nonredundant networks as safety nets (Batjargal, 2003b; Ostrom, 2005a). The concentration of political power in the executive branches of government leaves judicial authorities weak (Shleifer, 2005). These conditions increase transaction costs for entrepreneurs, causing them to use private channels (e.g., trusted intermediaries) through which they can complete important transactions (McMillan \& Woodruff, 1999).

Weak economic institutions (e.g., institutions responsible for capital availability and market liquidity) directly and indirectly influence entrepreneurs' network structures (Aldrich \& Ruef, 2006; Batjargal, 2006). For example, a shortage of loans and investment funds for start-up ventures motivates entrepreneurs to search for financial resources from diverse sources such as business angels, neighborhood credit associations, and other informal financial networks (McMillan \& Woodruff, 1999; Tsai, 2002). Further, money-market illiquidity and inflexible exchange rates disadvantage new ventures disproportionately. Therefore, entrepreneurs mobilize bridging ties in their networks to overcome these difficulties generated by weak eco- nomic institutions (Batjargal, 2005; Stam \& Elfring, 2008).

Interventionist regulatory institutions (e.g., overly bureaucratic registration procedures) produce a great deal of institutional inefficiencies that increase entrepreneurs' transaction and opportunity costs (Ardagna \& Lusardi, 2010; Ostrom, 2005b; World Bank, 2010). These inefficiencies force entrepreneurs to employ particular networkbased strategies (e.g., relational contracting) to reduce transaction costs (McMillan \& Woodruff, 1999). Networks rich in structural holes enable entrepreneurs to obtain permissions, licenses, and quotas and to re-enforce contracts and curb the predatory prerogatives of the government, because these ties serve as bridges to valuable contacts in distant social clusters (Batjargal, 2003a, 2003b; Frye, 2000; Frye \& Shleifer, 1997).

The confluence of weak and inefficient political, economic, and regulatory rules heightens the value of diverse and loose-knit networks through several mechanisms, such as the dynamics associated with negative mutual reinforcement and synergy (Schneider \& Karcher, 2010; Wilson \& Herzberg, 2000), increased institutional conflicts and contradictions (Hancke, 2010; Pache \& Santos, 2010; Seo \& Creed, 2002), and institutional deterioration and reversals (Acemoglu et al., 2005; North \& Shirley, 2008). The distrust in political institutions enhances entrepreneurs' reliance on network-based strategies and tactics that are used to cope with weak economic institutions and inefficient regulations (Spicer \& Pyle, 2002). The chronic financial disadvantages generated by inferior economic institutions justify and perpetuate obtaining financial and other tangible resources from network ties, which are often cultivated for purposes of circumventing intrusive regulatory institutions (Malesky \& Taussig, 2009; World Bank, 2010). Weak legal protections through court systems together with predatory inclinations of government bureaucracies often make informal channels of protection the primary and perhaps the only alternative available to entrepreneurs (Volkov, 2002). The legal and administrative restrictions on business activities-in combination with frequent shortages of cash, foreign currency, and supplies-compel entrepreneurs to rely to a greater degree on loose-knit personal networks (Tsai, 2002).

The combination of weak and inefficient institutions serves as a catalyst for conflicts within an institutional system (Hancke, 2010). For example, burdensome regulations clash with market-based 
economic institutions that require relative freedom and strong legal foundations to operate effectively (Bjornskov \& Foss, 2008; Nee, 2005; North \& Shirley, 2008). Inefficient (often contradictory) regulations exacerbate institutional confusion and impose competing demands on organizations that can be especially challenging for new firms (Pache \& Santos, 2010). Amalgamated weak and inefficient institutions often lack conflict resolution mechanisms, thereby potentially escalating disputes among different actors (Ostrom, 2005a). The series of weak and inefficient institutions often results in institutional deterioration that increases the risk for entrepreneurs in the institutional context (Acemoglu et al., 2005; North \& Shirley, 2008). Frequent policy reversals precipitate constant rule changes that amplify institutional uncertainty.

Thus, negative synergy, institutional conflicts, and institutional deterioration generate risky and adverse institutional environments for entrepreneurs (Guseva \& Rona-Tas, 2001; North, 1990; World Bank, 2010). As a result, entrepreneurs are forced to cultivate networks rich in structural holes to cope with such adversity and to access resources (North, 1990). These negative institutional processes heighten the value and utility of entrepreneurial networks rich in structural holes (Ostrom, 1990, 2005b); entrepreneurs use networks as substitutes for weak and inefficient formal institutions. These arguments lead to the following hypothesis:

Hypothesis 1. The confluence of weak and inefficient institutions has a positive effect on entrepreneurial networks' structural holes (i.e., entrepreneurs' networks have more structural holes).

\section{Confluence of Weak and Inefficient Institutions and New Venture Growth}

A single weak or inefficient institution can adversely influence the revenue growth of young firms (Frye \& Shleifer, 1997). However, the combination of multiple weak and inefficient institutions has a strong, cumulative, negative effect on revenue growth, because these institutions reinforce one another's harmful effects (Schneider \& Karcher, 2010; Wilson \& Herzberg, 2000), impose contradictory demands on new firms (Pache \& Santos, 2010), and tend to be unstable (North \& Shirley, 2008; Sobel \& Coyne, 2011). The negative influences of weak and diffuse institutions increase the challenges of identifying growth opportunities, create higher transac- tion costs, and constrain access to resources. The confluence of these institutions makes it difficult to develop effective sales and marketing strategies, especially for new venture firms. These problems are reflected in lower revenue growth (Boettke et al., 2008; Fogel et al., 2006; Ostrom, 2005a; Ovaska \& Sobel, 2005).

Weak political institutions often impose restrictions on social activities that in turn hinder entrepreneurial opportunity identification and innovation (Batjargal, 2007a; Tsai, 2007). Weak political institutions and bureaucratic regulatory controls tend to foster corruption and bribery that hinder entrepreneurs' risk taking (Tonoyan, Strohmeyer, Habib, \& Perlitz, 2010). Under these conditions, new ventures are less likely to grow.

Inefficient regulatory (including legal) institutions often result in insecure property and contractual rights, which negatively influences both growth incentives and intentions, because entrepreneurs are unsure of their ability to obtain and retain adequate returns from a venture's strategic actions (e.g., introduction of new product) (Baumol, 1990; Desai, Gompers, \& Lerner, 2005; Frye \& Shleifer, 1997). The overly bureaucratic rules redirect entrepreneurs' attention, time, and energies away from revenue generation activities and thereby increase overall opportunity costs (World Bank, 2010).

Weak economic institutions are especially harmful to young firms because they constrain entrepreneurs' access to equity and debt capital (Batjargal \& Liu, 2004; Malesky \& Taussig, 2009). The limited supply of funds for capital investment reduces operating working capital available for production and services, thereby restricting revenue growth (LeLarge, Sraer, \& Thesmar, 2010). Similarly, a shortage of or restrictions on the use of foreign currency hampers new ventures' ability to import new technologies, product components, and raw materials and to sell their products in overseas markets (Tsai, 2002). The combination of weak and inefficient institutions results in negative synergy because of destructive mutual reinforcement and increased institutional contradictions and reversals that disrupt venture growth processes and trajectories (North \& Shirley, 2008). Drawing on these arguments, we propose:

Hypothesis 2. The confluence of weak and inefficient institutions has a negative effect on the revenue growth of new ventures. 


\section{Networks' Structural Holes and New Venture Growth}

As an alternative channel for resource acquisition, a network's structural holes enable entrepreneurs to access informal resource holders who partially operate beyond formal institutional arrangements (e.g., overseas informal investors) (Batjargal, 2007a; Burt, 1992). In contrast, dense networks with fewer structural holes connect entrepreneurs with local resource holders who often operate within a shared institutional order (Granovetter, 1995). Entrepreneurial networks rich in structural holes facilitate a new venture's revenue growth through six mechanisms: access to nonredundant information, knowledge, and referrals; brokerage; access to tangible resources; structural autonomy; social and emotional support; and the transitivity mechanism (Burt, 1992; Granovetter, 1973, 1995; Stam \& Elfring, 2008; Stuart \& Sorenson, 2007).

Loose-knit and diverse networks rich in structural holes enable entrepreneurs to obtain nonredundant private information about sales opportunities (e.g., information about new market segments for existing products, new products for current clients, and new distribution channels in a timely fashion), because these networks serve as bridging ties to distant clients (Batjargal, 2010a; Stam \& Elfring, 2008; Stuart \& Sorenson, 2007). The sales referrals and recommendations from trusted ties generate higher revenues, and interpersonal trust and expectations between entrepreneurs and referees are likely to transfer to third parties (e.g., new clients) (Castilla, Hwang, Granovetter, \& Granovetter, 2000). Such relational trust lubricates and speeds up the sales processes of customization, pricing, delivery, and after-sales services (Uzzi, 1997).

Brokerage is a process by which intermediary actors facilitate transactions between other actors lacking access to or trust in one another. The brokers generate returns each time they broker an exchange (Marsden, 1982). Entrepreneurs can benefit in these cases by serving as intermediaries between potential suppliers and customers from distant network clusters (Burt, 1992).

The bridging ties to different social clusters enhance entrepreneurs' access to diverse tangible resources (Batjargal, 2010b; Stam \& Elfring, 2008). Having access to a broader set of resources in- creases the probability that entrepreneurs will have access to the type and amount of resources needed at any given time. The increased flows of money, materials, and technologies enable entrepreneurs to formulate and execute more aggressive sales and marketing strategies that stabilize or enhance revenue streams and make income growth sustainable over the long term (Batjargal \& Liu, 2004).

An important but sometimes overlooked mechanism through which structural holes generate benefits is the relative structural autonomy that lowdensity networks generate. Entrepreneurs who rely on disconnected network clusters are less dependent on a few powerful network members (e.g., suppliers and customers), who might attempt to exercise control over the entrepreneurs. Structural independence gives entrepreneurs freedom to act on revenue opportunities without compromising their sources of resources and support (Burt, 1992).

Structural holes can also provide potential socioemotional benefits to entrepreneurs from diverse ties. The different people who populate entrepreneurs' networks, such as mentors, friends, and family members, each satisfy different socioemotional needs of entrepreneurs (Carsrud, Gaglio, \& Olm, 1987). While mentors provide encouragement for business achievements, friends and family help entrepreneurs to cope with work-related stress and the competitive pressures endemic to entrepreneurial ventures. Importantly, disconnected support networks make it less likely that social problems and the challenges they generate would migrate from work to families and from families to work. In this sense, loose-knit networks serve as a buffer or protection for entrepreneurs. This situation promotes enhanced confidence, commitment, and psychic resources on the part of the entrepreneurs, thereby better enabling them to concentrate on revenue generation activities (Krueger \& Dickson, 1994).

The last mechanism that facilitates revenue growth is transitivity of network triads. When an entrepreneur connects and integrates two trusted contacts from distant network clusters, positive outcomes, such as the integration of different knowledge stocks and resources, access to venture capital, and alliance creation, can occur (Batjargal, 2007b; Granovetter, 1973). These outcomes have the potential to contribute to higher revenue growth in entrepreneurial ventures. For example, the combination of different knowledge stocks and/or other resources potentially allows firms to identify and exploit new market opportunities. 
Summarizing these arguments, we propose:

Hypothesis 3. Entrepreneurial networks' structural holes have a positive effect on the revenue growth of new ventures.

\section{The Moderating Role of the Confluence of Weak and Inefficient Institutions}

The effects of an entrepreneurial network's structural holes on revenue growth are greater when the confluence of weak and inefficient institutions creates an adverse institutional order with which entrepreneurs must cope. More specifically, we expect that networks rich in structural holes serve as substitutions for weak and inefficient formal institutions helping entrepreneurs to access informal resource holders who partially operate beyond formal institutional arrangements (Deeg, 2005; Nee, 2005; Ostrom \& Ahn, 2009). Resources accessed from these sources are generally helpful, but they have greater importance and are critical to enhancing venture growth when formal institutions are weak and inefficient.

Institutional environment represents an important component of the context within which new venture firms must operate and seek growth. While a single weak institution or several inefficient institutions may have small or negligible effects on entrepreneurial growth (Tzeng et al., 2011), the confluence of multiple weak and inefficient institutions creates a hostile institutional context for entrepreneurs due to negative synergy among the various institutions (e.g., negative reinforcement, and institutional conflicts and deterioration) (Volkov, 2002). The adverse institutional order results in more challenging opportunity identification, high transaction costs, constrained access to resources, and inadequate sales strategies. Under these conditions, entrepreneurs need to mobilize their personal networks as alternative channels to increase revenues, because the formal institutional support available is deficient (Boettke et al., 2008; Heberer, 2003). The diverse networks rich in structural holes substitute for the functions generally provided by institutions and thereby enable entrepreneurs to recognize new revenue opportunities efficiently (e.g., cost effectively), reduce transaction and opportunity costs, access financial and material resources from informal channels, and support their actions to formulate and execute sales-marketing strategies (Aidis, Estrin, \& Mickiewicz, 2008;
Aoki, 1994; Batjargal, 2010a; Granovetter, 1995; Tsai, 2002; Webb, Kistruck, Ireland, \& Ketchen, 2010). Thus, personal networks compensate for the deficiencies of multiple weak and inefficient institutions. As a result, the networks become even more important in the context of an adverse institutional order, and thus, entrepreneurs depend more heavily on them under these conditions.

Networks supplement or supplant weak and inefficient rules and prescriptions when the goals, intentions, and expectations of formal institutional actors and entrepreneurs are incompatible and conflicting (Estrin \& Prevezer, 2011). One pervasive outcome of weak and inefficient institutions is rampant corruption, in which formal institutional actors (rule makers and enforcers) become personal rent seekers (Baumol, 1990; Boettke et al., 2008). And, when formal institutions are antagonistic, a reliable protection is trusted social relationships (Ostrom \& Ahn, 2009). Diverse network ties can be used for protection when the intentions and behaviors of multiple institutional actors and entrepreneurs are hostile (Helmke \& Levitsky, 2004). For example, by mobilizing members of their dispersed networks, entrepreneurs may be able to avoid paying illegal fees and bribes and to secure their property (Batjargal, 2003b; Li, Meng, Wang, \& Zhou, 2008; Volkov, 2002). The transaction costs of using ties as protection can sometimes be high, but the costs are lower than acquiescing to corruption. And these ties will allow entrepreneurs to enhance their venture's growth while simultaneously avoiding the costs emanating from corrupt practices.

Thus, the combination of weak and inefficient institutions leads to greater returns from networks for entrepreneurs. In other words, this type of institutional environment enhances the importance of and the value created from entrepreneurial networks. Specifically, the confluence of weak and inefficient institutional rules enhances the positive effects of a network's structural holes on the revenue growth of new ventures. Thus, we hypothesize:

Hypothesis 4. The confluence of weak and inefficient institutions positively moderates the effect of networks' structural holes on revenue growth of new ventures. The positive relationship between structural holes and revenue growth is stronger in a more adverse institutional order due to the confluence of weak and inefficient institutions. 


\section{METHODS}

\section{Country Institutional Polycentricity}

We chose China, Russia, France, and the United States as country contexts for this study for the following reasons. First, the four nations indicate varying confluences of different political, regulatory, and economic institutions for entrepreneurship (World Bank, 2010). China combines communist political institutions, a mixed legal system of communist and German laws, and hybrid economic institutions of state, collective, and private ownership. In contrast, Russia blends a semidemocratic political institution, a formerly socialist judicial structure, and a transitioning overregulated market economy. The French institutional system is comprised of a European political institution with a powerful presidency, a civil law tradition, and a coordinated market economy. The United States has a liberal presidential political institution, a common law system, and a liberal market economy.

Second, the institutional order in each country represents a unique configuration of institutions, in which each type of institution has a different weight and influence within the whole system. For example, political institutions have relative dominance over other types of institutions in China (Nee, 2005; Xu, 2011), whereas in Russia, the bureaucratic regulatory institutions have a great deal of influence on economic and social institutions (Shleifer, 2005). In contrast, social welfare institutions carry strong weight within the French national system, and market-based economic institutions exert strong influence on political and regulatory institutions in the United States.

Third, the evolutionary trajectories of multiple institutions in each country differ. For example, in China, while political institutions preserve the status quo, private property-based market institutions are growing strong. In Russia, there is an increasing gap between predatory bureaucracies and private property-based institutions (Batjargal, 2007c). The social welfare system in France is expanding, thereby placing increasing pressure on financial institutions. In the United States, a tenuous balance between political, regulatory, and economic institutions is maintained via the country's legal system and mature institutions. Thus, the different institutional confluence, configuration, and evolutionary trajectories in these countries provide useful settings in which to test the theoretical ideas based on institutional polycentricity.

\section{Sample, Procedure, and Survey Data}

We conducted structured telephone interviews with 205 Chinese, 105 French, 172 Russian, and 155 US entrepreneurs. The Chinese and Russian data were collected in the summer and fall of 2005; the American data were collected in the winter of 2006 and spring of 2007; and the French data were collected in the winter and spring of 2007.

A particular challenge in international entrepreneurship research is to achieve methodological and sampling equivalence across international contexts (Cumming et al., 2009). We adopted the following seven sampling criteria and procedures. First, we identified entrepreneurs in each country and city using various information sources. ${ }^{2}$ In the United States, entrepreneurs were identified through the Dun \& Bradstreet database and through minorityand women-based business directories in Texas and Arizona. In Russia and China, there is no equivalent of Dun \& Bradstreet. Therefore, our sample was derived from a number of data sources: government-created databases, telephone directories, and specialized business directories in Beijing and Moscow. In France, we identified entrepreneurs from entrepreneurs' associations (e.g., Centre des Jeunes Dirigeants and Club des Entrepreneurs) and leading business school alumni directories. ${ }^{3}$ Although the use of various information sources makes sampling less systematic, this approach enabled us to identify more and diverse ventures and, arguably, made the sample more random because various databases and directories are likely to counterbalance one another's biases. ${ }^{4}$ Second, we

\footnotetext{
${ }^{2}$ The complete list of all information sources in Chinese, Russian, French, and English is available upon request.

${ }^{3}$ Centre des Jeunes Dirigeants and Club des Entrepreneurs are two of the largest and most active entrepreneurial associations in France, and they operate mostly in large cities such as Paris.

${ }^{4}$ The usage of many different information sources for identification of sample populations of new ventures is necessary in emerging economies for the following reasons. First, in China and Russia there are no complete, systematic, and well-established databases of new ventures. If there are some, access to them is limited for scholars-in particular, for those scholars based in the West. Therefore, researchers are forced to use only publicly available information sources. Second, in the emerging economies, certain types of enterprise databases, company directories, and membership lists of associations are likely to be biased in some dimensions,
} 
oversampled women entrepreneurs in each country, because they are fewer than men entrepreneurs around the world (Langowitz \& Minniti, 2007). Third, we tried to avoid sampling low-growth-intention "life-style" start-ups, self-employed sole entrepreneurs, and necessity-based, survival-type ventures, particularly in the emerging economies of China and Russia (Langowitz \& Minniti, 2007). Therefore, we interviewed entrepreneurs in large metropolitan areas including Beijing, Moscow, Houston, Phoenix, and Paris. Fourth, a firm had to be eight years old or younger, in line with previous research on new ventures (Zahra, 1996). Fifth, the firm could not be a franchise, subsidiary, or spinoff of an established organization (to ensure that the venture has true financial and managerial independence). Sixth, each new venture had to be domestically owned (i.e., with no foreign stake in the venture). Seventh, each respondent had to be a majority owner of and have a decision-making role in the firm (e.g., CEO).

In China, 817 ventures met our sampling criteria. We successfully contacted 513 firms but could not reach the remaining 304 ventures. The response rate was 40 percent in China (205 firms responded).

because the purposes of creating databases and directories differ from organization to organization. For example, local governments may set up databases for collecting taxes and for policy purposes such as the promotion of women's or high-tech entrepreneurship. The specialized directories of women's business associations (e.g., "Women entrepreneurs in Beijing's Zhongguancun hightech district”) will list only those women entrepreneurs who are active members of associations, clubs, and other organizations. Databases of venture capital and consulting companies (e.g., Zero2ipo) in China are likely to list firms in certain industries (e.g., IT or nanotechnology) or high-growth firms. In addition, many databases and directories contain information about those ventures registered in a particular location, and may not have information for those ventures registered elsewhere but operating mainly in that location. For example, when we collected interview data in Beijing and Moscow, we realized that there were many ventures that operated mainly in Beijing and Moscow but were registered elsewhere. These ventures were not listed on any of the local government-run databases but came up in other directories. Therefore, the use of various information sources is likely to counterbalance systematic biases of different databases and directories and make the sample more random and balanced. Third, World Bank researchers adopted a similar approach by using multiple information sources and found this approach to be valid (Djankov et al., 2006).
In Russia, 652 ventures met the sampling criteria. We were able to contact 507 firms but could not reach the remaining 145 firms. The response rate was 30 percent in Russia (172 firms). The response rates in France and the United States were 37 percent (105 firms) and 30 percent (155 firms), respectively. The overall response rate of 35 percent (637 responded out of 1,820 contacted) compares favorably with most network surveys (Marsden, 1990). More than 80 percent of entrepreneurs stated that high growth is the most important goal. This result confirms that the majority of the ventures were high-growth-intention start-ups.

Trained interviewers conducted telephone interviews using a specially designed questionnaire. The survey instrument was first developed in English and then translated into Chinese, Russian, and French. We employed back translation to ensure equivalence in the survey questions across the four countries. As this is a cross-level study, we collected institutional data at the country level, social network data at the individual level, and venture growth data at the firm level (Hitt, Beamish, Jackson, \& Mathieu, 2007).

\section{Measures}

Independent variables. In this study, we used the strength-weakness composite institutional variable to capture the confluence of weak and inefficient political, regulatory, and economic institutions at the national level. The partial least squares (PLS) analytical tool provided differential weights for each component within the composite (latent) variable. We focused on national institutions because they provide a general framework within which subnational institutions are nested and embedded (Ostrom, 2005a). Data on formal institutions were obtained by gathering information on country-level political, regulatory, and economic environments. We used the data from Holmes et al. (2013) and the output of an exploratory factor analysis of the institutional variables that they completed (see Appendix A). The data were reduced to 20 variables, which loaded on four factors-political democracy, regulatory control, capital availability, and market liquidity - as noted in Appendix B. Political democracy reflects the means through which government officials and other individuals enact changes in formal institutions. Regulatory institutions establish and enforce laws and policies that govern business activities. Capital availability influences the investment decisions of organiza- 
tions and individuals by affecting both their access to capital and its value. Market liquidity captures a country's liabilities, exchange rate, and liquidity. To measure institutional weakness/inefficiency, we reverse-coded the factors of political democracy, capital availability, and market liquidity. The regulatory control institutions variable stands in contrast. Although some legal and regulatory protections are desirable for entrepreneurs, overly bureaucratic rules and procedures can be onerous and highly inefficient, especially for entrepreneurs. In effect, such rules and policies greatly increase the transaction costs and opportunity costs for entrepreneurs. A higher institutional score reflects a greater confluence of weak and inefficient formal institutions. The latent variable institutions was then created using these factors, where political democracy (0.90), regulatory control (0.99), capital availability (0.84), and market liquidity (0.89) load positively in the PLS analysis.

We used this measurement for the following reasons. First, the operationalization and measurement are consistent with the concept of institutional multiplicity. We examine one form of institutional multiplicity: confluence of various types of institutions (political, regulatory, and economic). Second, this measurement enables us to examine the effects of national-level formal institutions on outcomes in a composite and cointegrated manner. Therefore, the measurement is consistent with theoretical arguments and this study's goals.

We used the name generator method (Burt, 1992; Marsden, 1990) to obtain data on entrepreneurs' personal (egocentric) networks involving three contents: business advice, business resources, and emotional support. We employed the name generator method because it enables measuring structural properties of networks (i.e., density and structural holes) thoroughly while being less likely to suffer from social desirability bias than other methods, including the position generator method. Each respondent was asked to provide the first names or the surnames of up to five individuals in his or her network from whom he or she had obtained business advice (e.g., information and suggestions), business resources (e.g., finances, supplies), and emotional support in the last six months. ${ }^{5}$ Each

\footnotetext{
5 To preserve the anonymity and confidentiality of network contacts, we asked the Chinese respondents to provide surnames of their contacts (e.g., Wang or Li), and the American, French, and Russian respondents to pro-
}

contact was named only once. For each contact, respondents also answered the question "How close do you feel to this person" as "very close," "close," "neither close not distant," or "distant." Similarly, the respondent reported his/her perception of the relationship between two pairs of contacts as "close," "neither close nor distant," or "distant." "Distant" was defined as "two individuals rarely work together, are strangers, or do not enjoy each other's company." We used Burt's (1992) measure of network constraint to capture structural holes:

$$
C_{i}=\left(p_{i j}+\sum_{q=1}^{N} p_{i q} p_{i j}\right)^{2}, q \neq i, j,
$$

where $p_{i j}$ is the proportion of total relational strength that $i$ directly allocates to $j, p_{i q}$ is the proportion of total relational strength that $i$ devotes to $q$, and $p_{q j}$ is the proportion of total relational strength that contact $j$ devotes to contact $q$. We used UCINET 6 software to calculate the network constraint score. Structural holes is measured as $1 \mathrm{mi}-$ nus the network constraint score, with larger scores denoting more structural holes. We asked a series of additional questions about each contact in each network (eliciting, e.g., how many years the respondent had known the contact, the contact's gender, and the nature of the tie, such as "family").

Dependent variable. We use revenue growth as a proxy for venture performance because it is a common measure of the success of new ventures (Baum, Locke, \& Smith, 2001) and is more appropriate than alternative measures in cross-country and cross-industry comparative contexts (Brush \& Vanderwerf, 1992). In the interview, we asked for revenue growth information for the four years prior to the time of the telephone survey. Revenue growth is the difference between sales in two consecutive years divided by sales one year earlier. The variable revenue growth is the sum of revenue growth percentages divided by the number of revenue years.

Control variables. We control for firm age, measured as years since the date of founding, and firm size, measured as the number of full-time employees. We control for demographic attributes and human capital of the entrepreneurs. Entrepreneur's age is measured in years, and entrepreneur's edu-

vide first names (e.g., Peter, Helen, or Anne-Marie). Surnames are common but first names are unique in China, whereas in Russia, France, and the United States, first names are common but surnames are unique. 
cation is coded as 1 when the entrepreneur's education is less than an undergraduate degree, 2 when the entrepreneur has an undergraduate degree, 3 for a master's degree, and 4 for a doctorate. We control for entrepreneur's gender using a dummy variable (1 = “woman”). Entrepreneur's managerial experience is the number of years the entrepreneur worked as a manager before starting the new venture. We control for network size, network density, and composition (women and family ties) in order to estimate the net effect of structural holes. Network size is the sum of the number of contacts named in the three networks. Network density measures the extent to which contacts (alters) are connected to each other (Marsden, 1990). This variable is calculated by dividing the total number of identified relationships between the alters by the total possible number of ties, which for an undirected graph is:

$$
\frac{\sum_{i=1}^{N} \sum_{j=1}^{N} a_{i j}}{N(N-1)},
$$

where $a_{i j}$ is 1 (indicating the existence of a close relationship between $i$ and $j$ ), 0.5 (indicating the existence of neither close nor distant relationship), or 0 (indicating the absence of relationship); and $N$ is the number of contacts (alters). The women ties variable is measured as the percentage of women in an entrepreneur's network (Batjargal, Hitt, Webb, Arregle, \& Miller, 2009). The family ties variable is measured as the percentage of kin in an entrepreneur's network. Proxies for the industry environment, industry dynamism and munificence, were measured using Keats and Hitt's (1988) method. First, each new venture was coded on industry affiliation: trade, service, information technology (IT)/software, biotechnology/pharmaceuticals, or light manufacturing. Munificence is measured as the growth in revenues in each of the above industries, that is, the regression slope coefficient of revenues for the period 2000-04 (for five years in each industry). Dynamism is measured as the variation in revenues over this period in each industry-that is, as the standard error of the regression slope coefficient of revenues. This figure is then divided by the industry mean in revenues to standardize the values across industries. These two variables were used as manifest variables of a latent variable industry, reflecting industry environment. The data sources used to gather revenue data for China, Russia, France, and the United States are listed in Appendix C. Finally, we control for national cul- ture because it affects formal institutions as well as entrepreneurial activities (Holmes et al., 2013). To measure culture in each country, we used data from the Global Leadership and Organizational Behavior Effectiveness project (GLOBE) (House, Hanges, Javidan, Dorfman, \& Gupta, 2004). Specifically, we used in-group collectivism, power distance, uncertainty avoidance, and gender egalitarianism as cultural practice variables. These four variables were used as manifest variables of the latent control variable culture. Higher scores mean greater collectivism, power distance, and uncertainty avoidance, and lower gender egalitarianism.

\section{Data Validity}

We conducted validation checks on our data. In the US sample, validation was performed on a randomly selected group of 34 entrepreneurs from the sample. For this group, we readministered the survey three months, on average, following the initial survey to determine the reliability of the entrepreneurs' responses. We found the agreement between the initial and follow-up data to be more than 80 percent for venture characteristics such as firm size, firm age, and revenue growth. Follow-up questions suggested that the few differences were related to actual changes in the ventures (e.g., further growth in revenue or personnel). In France, we re-interviewed 11 of the sampled entrepreneurs (10 percent of the French sample) an average two months after the initial data collection. We asked the same questions and found 95 percent agreement on networks, venture characteristics, and revenue across the interviews.

In China and Russia, we used a different procedure to validate the data. By selecting every fifth or sixth entrepreneur in our samples, we created lists of 15 women-owned and 15 men-owned ventures in each country. We submitted revenue growth data of 30 Beijing-based firms to the Government Tax Bureau in Beijing and 30 Russian firms to the Taxation Department of the Moscow City Government for the cities where these ventures operate. We asked government officials to confirm whether our data were consistent with their data. We received confirmation that our revenue growth data for 27 Chinese firms (90\%) and 24 Russian firms (80\%) were consistent with the data in the respective tax offices. Social network data were validated through interviews. We asked for the telephone number of one of the contacts listed in the business resource networks. We obtained telephone numbers for 18 
contacts in China and 12 contacts in Russia. We telephoned these contacts and validated the entrepreneurs' responses. We asked the contacts for their functional backgrounds and relational bases ("How did you get to know this person?"). The responses of 17 Chinese contacts (94\%) and 10 Russian contacts (83\%) were consistent with the data we obtained in the survey from the entrepreneurs. According to James, Demaree, and Wolf (1984), an agreement of at least 80 percent between multiple raters is necessary to establish reliability. The evidence from our validation procedures suggests that the network and revenue growth data are reliable in all four samples.

\section{Analyses}

Before hypothesis testing, we performed additional data quality checks. First, we examined the data for outliers. Using scatterplots, casewise diagnostics, and Cook's distance analysis (Cook, 1979), we found three outliers in the relationship between network size and revenue growth. These outliers were excluded from further analyses. Second, some entrepreneurs were reluctant to provide revenue growth data, resulting in 21 percent of the sample having missing data on the major dependent variable. Following Little and Rubin's (2002) guideline, we used the mean revenue growth of each country to substitute for missing data in that country. Analyses using the sample both with and without the mean substitution yielded similar results. We reported the results using the sample with mean substitution to conserve sample size and maintain statistical power. ${ }^{6}$

We used PLS to analyze the data for hypothesis testing because it calculates the confluence of multiple institutions by differentially weighting the four institutional factors. As a modeling approach, PLS has been used in management research fruitfully (Henseler, Ringle, \& Sinkovics, 2009; Hulland, 1999). In contrast to covariance-based structural equation modeling such as LISREL, PLS is a component-based structural equation modeling approach (Esposito Vinzi, Chin, Henseler, \& Wang, 2010). The main advantages of PLS are that it relies on less stringent assumptions about the distribution of the variables and is able to estimate complex models with many latent and manifest variables

\footnotetext{
${ }^{6}$ The results of the analyses without mean substitution are available upon request.
}

such as our institutional and culture variables (Chin, 2010; Hulland, 1999; Shamir, Zakay, \& Popper, 1998). The results of PLS analyses are evaluated by considering the composite reliability, average extracted variance, value of $R^{2}$, and bootstrap for the $t$-values (Chin, 2010; Henseler et al., 2009; Hulland, 1999). Therefore, we chose PLS considering the measures of institutions, culture, and industry, and the relatively fewer variations in the country-level variables. We used SmartPLS software to carry out the analyses (Ringle, Wende, \& Will, 2005).

\section{RESULTS}

Table 1 presents the descriptive statistics and Pearson's correlations of all study variables. The average firm size is 36 full-time employees (s.d. = 61.5). Twenty-five percent of the ventures were in IT, software, and biotechnology industries; 46 percent were in trade and services; and the remaining 29 percent were in other industries. The average age of the entrepreneurs was 39 years (s.d. $=8.5$ ). The mean network size was 5.7 contacts (s.d. = 2.5), and the mean structural holes score was 0.49 (s.d. $=0.21$ ). The finding on the mean network size is consistent with the findings of previous surveys of egocentric networks in the general population (Marsden, 1990; McPherson, Smith-Lovin, \& Brashears, 2006) and of entrepreneurs (Aldrich, Reese, \& Dubini, 1989; Batjargal, 2007c). The average revenue growth was 36 percent (s.d. $=61$ ).

Table 2 illustrates the convergent and discriminant validity analyses for the PLS models explaining network's structural holes and revenue growth of new ventures. The results indicate that institutions as an independent variable and industry and culture as control variables present strong convergent and discriminant validity.

Table 3 shows the results for the four hypotheses. Models 1 and 2 examine the effects of the confluence of weak and inefficient institutions on a network's structural holes. Model 1 is the base model for structural holes with control variables. Model 2 includes the effects of the confluence of formal institutions and shows a statistically significant positive effect on structural holes $(b=0.15, p<$ .05), providing support for Hypothesis 1.

Model 3 is the base model for revenue growth with controls. Due to the high correlation between network size and structural holes $(r=.67, p<$ .001), the former was excluded as a control in the testing of Hypotheses 2 through 4. Model 4 in- 


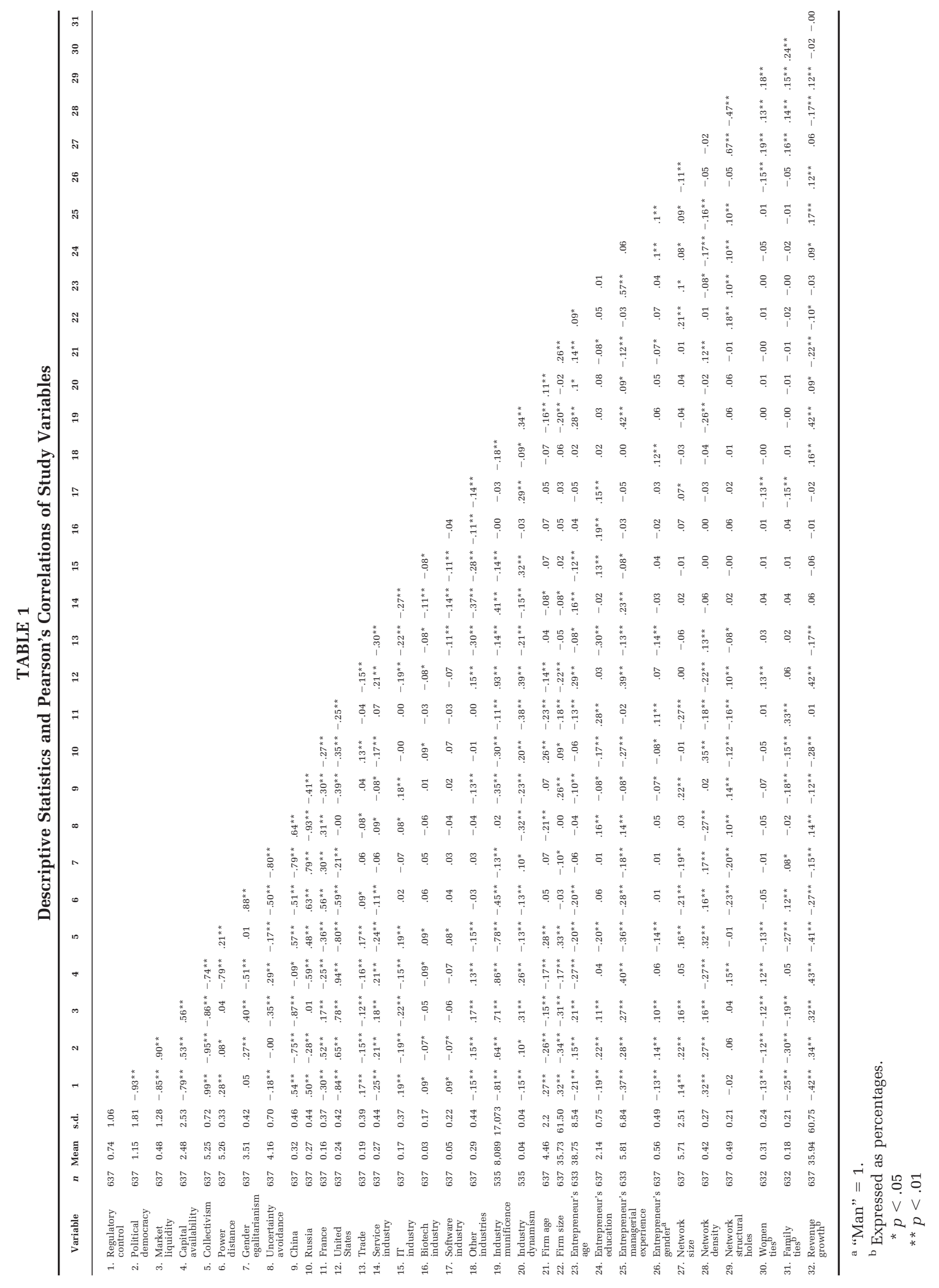


TABLE 2

Convergent and Discriminant Validity Analyses for PLS Models Explaining Structural Holes and Revenue Growth ${ }^{\mathrm{a}}$

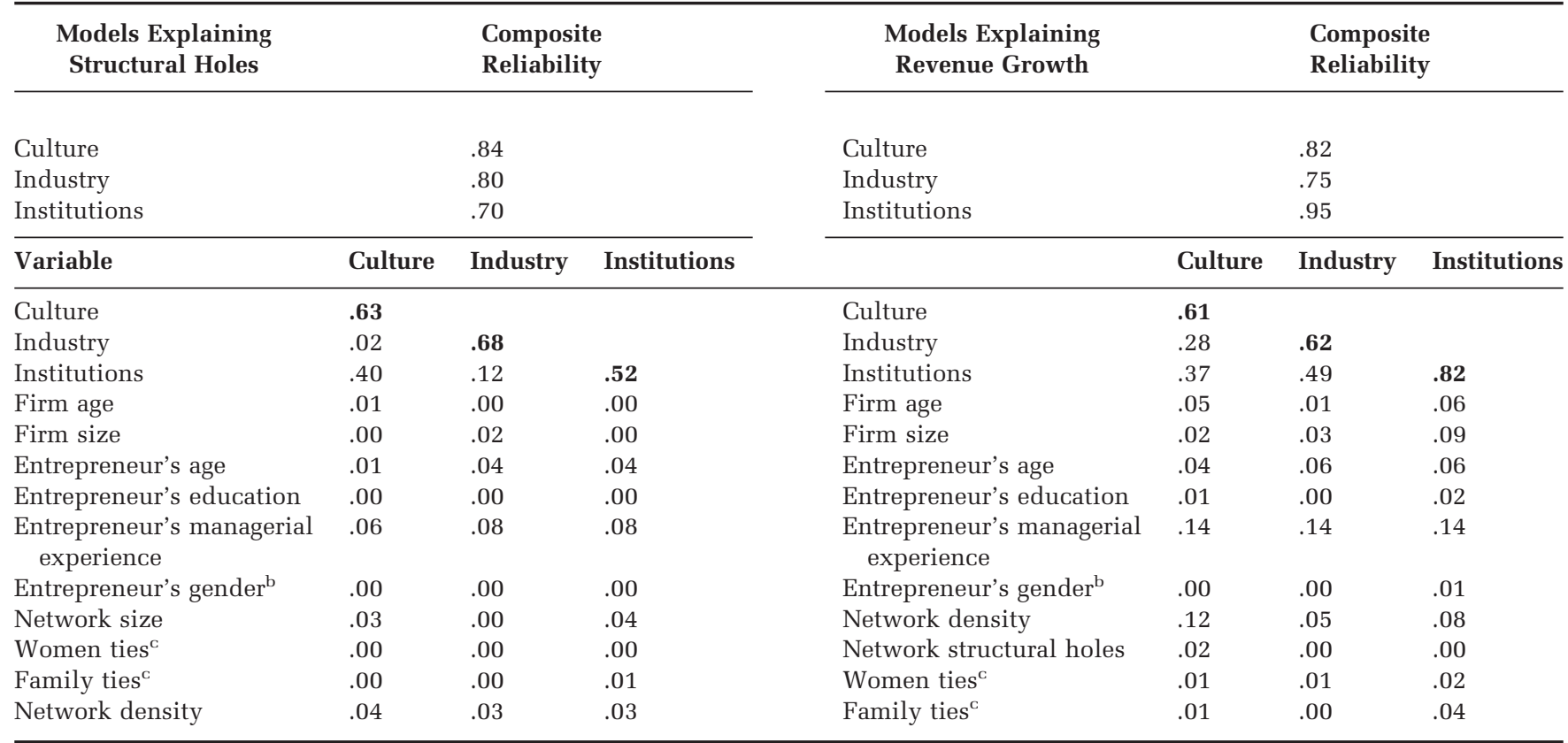

${ }^{a}$ Values in bold show the average variance extracted (AVE) by constructs. The other values are the squared correlations (Chin, 2010).

b "Woman" = 1 .

${ }^{\mathrm{c}}$ Expressed as percentages.

TABLE 3

Standardized Path (Regression) Coefficients from PLS Analysis Predicting Structural Holes and Revenue Growth

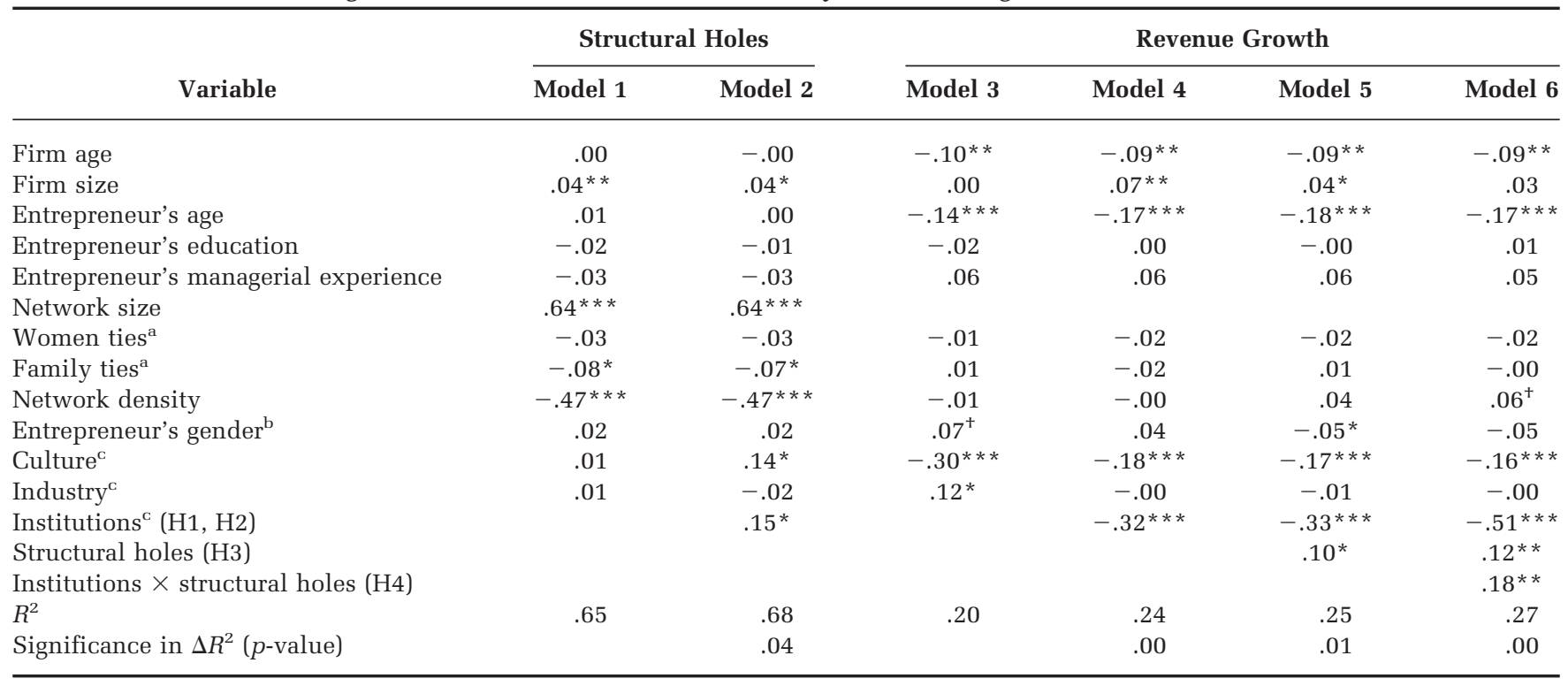

\footnotetext{
${ }^{a}$ Expressed as percentages.

b "Woman" $=1$.

${ }^{\mathrm{c}}$ Composite variables.

${ }^{+} p<.10$

${ }^{*} p<.05$

$* * p<.01$

$* * * p<.001$
} 
cludes the effects of the confluence of weak institutions on revenue growth and shows a statistically significant negative effect on revenue growth $(b=$ $-0.32, p<.001)$. Thus, Hypothesis 2 receives support. Model 5 reveals that the main effect of network's structural holes on revenue growth is positive and statistically significant $(b=0.10, p<.05)$, providing support for Hypothesis 3. Model 6 examines the two-way interaction effects of institutional confluence and structural holes on revenue growth. The results show that the interaction effect is positive and statistically significant $(b=0.18, p<.01)$, providing support for Hypothesis 4.

\section{Robustness Checks}

We conducted several additional analyses to check the robustness of the results. An important concern in entrepreneurship research is sample selection bias (Djankov, Qian, Roland, \& Zhuravskaya, 2006). Therefore, we performed the Heckman (1979) two-stage estimation procedure to determine if the effects of the independent and moderator variables on revenue growth, as shown in Table 3, are robust. In the first stage of this procedure, the inverse Mills ratio $(\lambda)$ was calculated using the total sample of the surveyed firms and the nonsurveyed firms. The nonsurveyed firms are the ventures that meet our sampling criteria but did not respond to our requests or that we were unable to reach. We dummy-coded the surveyed firms as 1 and used this variable as the dependent variable in a probit model. ${ }^{7}$ We used firm age, the trade/service dummy, and interaction of firm age and the trade/ service dummy as the independent variables in the probit model, because we had information on these variables in both the surveyed firms and the nonsurveyed firms. ${ }^{8}$ Then, the inverse Mills ratio was inserted into second-stage PLS regression models

\footnotetext{
${ }^{7}$ Because of the lack of data on nonsurveyed firms in France and the United States, the test was conducted using those from Chinese $(n=612)$ and Russian $(n=$ 480) firms. Therefore, we calculated the inverse Mills ratio using only the Chinese and Russian data. The nonsurveyed firm data from France and the United States are incomplete and sketchy due to the minor differences in the data collection procedures.

${ }^{8}$ We have information on gender and firm location; however, it would be inappropriate to use these two variables to test sample selection bias, because we deliberately oversampled women, and women entrepreneurs are distributed differently in various locations.
}

in which the dependent variable is revenue growth as a control variable. The inverse Mills ratio removes any potential bias due to sample selection and endogeneity (Hitt, Bierman, Uhlenbruck, \& Shimizu, 2006). Following the Heckman procedure, we excluded firm age and the trade/service dummy in the second-stage model in estimating new venture revenue growth. The results in Table 4 show that our findings are robust when we include the inverse Mills ratio as a control. ${ }^{9}$ These findings suggest that the original results are not subject to sample selection bias.

According to Stuart and Sorenson (2007), the cause-effect problem of networks versus venture performance in entrepreneurship research is a potential concern. Therefore, we conducted additional tests to ensure that the results do not suffer from reverse causality. Using the collected information on the duration of each respondent-alter (contact named) tie, we estimated the average dyadic ego-alter (ego is the respondent, and alter is the

\footnotetext{
${ }^{9}$ We have to use the total sample of 637 in the second stage (Table 4), because the regression results of the subsample of Chinese and Russian firms $(n=377)$ would be very different from the total sample due to the institutions hypotheses.
}

TABLE 4

Standardized Path (Regression) Coefficients from PLS Analysis Predicting Revenue Growth: Heckman's Two-Stage Estimation Procedure ${ }^{a}$

\begin{tabular}{lc}
\hline \multicolumn{1}{c}{ Variable } & Model 1 \\
\hline Firm size & -.00 \\
Entrepreneur's age & $-.16^{* * *}$ \\
Entrepreneur's education & -.01 \\
Entrepreneur's managerial experience & .06 \\
Network density $^{\text {Women ties }}{ }^{\mathrm{b}}$ & .05 \\
Family ties $^{\mathrm{b}}$ & -.03 \\
Culture $^{\mathrm{c}}$ & .02 \\
Industry $^{\mathrm{c}}$ & $-.13^{* * *}$ \\
Entrepreneur's gender $^{\mathrm{d}}$ & .02 \\
Inverse Mills ratio $(\lambda)$ & $-.06^{+}$ \\
Institutions $^{\mathrm{c}}$ & $.18^{* *}$ \\
Structural holes & $-.39^{* *}$ \\
Institutions $^{*}$ structural holes & $.16^{* * *}$ \\
\hline
\end{tabular}

\footnotetext{
${ }^{\mathrm{a}} n=637$.

${ }^{\mathrm{b}}$ Expressed as percentages.

${ }^{\mathrm{c}}$ Composite variables.

d "Woman" $=1$.

${ }^{+} p<.10$

$* * p<.01$

$* * * p<.001$
} 
contact) tie age for each respondent-the sum of years known for each alter divided by the number of alters. The data showed that the sample mean of dyadic tie age is 9.52 years for advice networks (s.d. $=7.12$ ), 7.8 years (s.d. $=6.00$ ) for business resource networks, 16.25 years (s.d. $=10.08$ ) for emotional support networks, and 11.14 years (s.d. $=5.69$ ) for the overall networks. In comparison, the mean firm age is 4.5 years $($ s.d. $=2.20)$ (Table 1$)$. These data indicate that the entrepreneurs knew most contacts well (i.e., for 6.7 years on average) before they started their ventures. Thus, the large time gap between tie cultivation and venture creation enables us to assume that networks influenced venture performance rather than venture performance affected network structure and composition.

\section{DISCUSSION}

Our findings suggest that the confluence of multiple weak and inefficient institutions is associated with larger numbers of structural holes in entrepreneurs' social networks. Such an institutional order also has a direct negative effect on new venture growth. A network's structural holes facilitate the revenue growth of new venture firms. Further, the confluence of weak and inefficient institutions enhances the effect of structural holes on new venture success. Thus, the results of this study suggest that the strength and efficiency of multiple formal institutions influence the effects of a network's structural holes on new ventures' revenue growth. Structural holes operate as a substitute for weak and inefficient rules and as a protection against destructive multiple institutional forces. Under these conditions, entrepreneurs benefit from their network's structural holes. However, those entrepreneurs who operate in settings where the entire institutional order is adverse and uncertain benefit more from their networks' structural holes. The results offer new and nuanced insights into the role of social networks for entrepreneurs operating in polycentric, weak, and inefficient institutional orders.

This research provides evidence of the contingent nature of both formal institutions and social networks for entrepreneurial success. In particular, it suggests that the concept of multiplicity as a part of institutional polycentrism plays an important role in the value of entrepreneurs' social networks for achieving success. Furthermore, the entrepreneurial networks serve different functions in different institutional orders. For example, we found that the institutional multiplicity characterized as the confluence of political, regulatory, and economic institutions had strong influences on both the social networks employed by entrepreneurs and on new venture growth. Additionally, when the combination of weak and inefficient institutions creates an adverse institutional order, lower-level informal institutions and networks (e.g., personal networks) become more important, suggesting the importance of institutional multiplicity and substitution as core concepts of the institutional polycentrism theory.

This research extends researchers' understanding of institutional polycentrism, showing the joint effects of the confluence of formal institutions (or lack thereof) and informal networks. And importantly, the effects of polycentric institutions also extend to entrepreneurial ventures. Finally, this research extends understanding of social network theory, suggesting that institutional rules influence the use and outcomes of entrepreneurs' social networks (Granovetter, 1995).

The theoretical framework developed and tested is original and scientifically useful in a number of ways. This is one of the first studies in management and entrepreneurship to employ the concepts of institutional multiplicity and institutional substitution from the theory of institutional polycentrism. Therefore, the theoretical perspective advances knowledge of polycentric institutions and polycentric institutional orders. Further, this study is one of the first to theorize and empirically examine the interactive influence of multiple types of formal institutions and personal networks on entrepreneurial outcomes (Brass et al., 2004; OwenSmith \& Powell, 2008), showing the influence of multiple-type institutions and networks on firm outcomes. Integrating two important research perspectives, namely, institutional polycentrism theory and social network theory, enhances understanding of the contingencies and contexts in which firms and entrepreneurs must operate. As a whole, the theoretical framework opens new directions in institution-based and network-based research.

The national institutional orders in China and Russia remain highly inefficient and weak, resulting in negative synergies, conflicts and contradictions, and deterioration (Batjargal, 2010a; Nee, 2005; Shleifer, 2005; Xu, 2011). Hence, guanxi (connections) networks in China (Chen, Chen \& Huang, 2013; Luo, Huang \& Wang, 2012) and svyazi (connections) networks in Russia serve as func- 
tional substitutes for formal institutions and as a protection against dysfunctional institutions (Djankov et al., 2006). This study confirms the importance of the structure of these two types of networks, respectively. Our study further confirms that even in strong institutional settings (such as the United States and France), networks' structural holes still offer the potential for positive returns to entrepreneurs.

This study focused on three types of formal institutions at one level. Future research should examine functional (what it does), process (how it performs and evolves), and normative (how it should be) aspects of multisource, multicode, multilevel, multitype, multisector, and multifunctional rules and norms. In particular, investigation of the relationships of multiple rules at the national versus local level, regulatory versus informal rules, and the different structures and compositions of networks is a promising direction for future research.

The institutional configuration processes (e.g., rule complementarity) should also be examined. Because polycentric institutions are dynamic, the centers of power and authority can change over time. Therefore, the causes and consequences of changing polycentric rules should be studied (Ostrom \& Basurto, 2011). Moreover, context-specific rules and norms should be identified and analyzed (Ostrom, 1990).

The current study focuses on institutions at the national level. Some may argue that local institutions may have a greater influence on entrepreneurship than national ones. However, local rules and prescriptions nested and embedded in national rules and norms can be complementary to higherlevel formal institutional arrangements (Ostrom, 2005a).

Further, polycentric institutional arrangements enable local actors to design unique problem-solving rules and avoid being caught between a false dilemma of "the state" and "the market" (Ostrom, 2010; Ostrom \& Walker, 2000). On the other hand, highly decentralized and overlapping rules may cause confusion, spread resources thinly, and trigger conflicts among competing institutional actors such as national versus local bureaucracies (Green, 2007; Ostrom, 1999a). It is possible that polycentric institutions have inverse U-shaped effects on certain outcomes as a result of both the advantages and disadvantages that polycentric prescriptions generate.
The development and validation of comprehensive empirical measures of institutional polycentrism are crucial for understanding of polycentric governance. Further, the differences and similarities between well-established concepts such as institutional complexity and institutional pluralism on the one hand, and institutional polycentrism on the other hand, require further investigation. Various types of polycentrism such as political, legal, market, regional, cultural, and network polycentrism should be examined and used to frame research questions (Green, 2007; Ostrom, 1999b).

At a broad level, our research indicates that institutional polycentrism influences how entrepreneurs network to support their growth objectives. This research also complements the extant research suggesting that institutional polycentrism influences the domain of activity pursued by entrepreneurs, and more specifically, whether and how individuals pursue entrepreneurship in the formal versus informal economy. While the formal economy encompasses activities that are considered legal and legitimate, the informal economy includes those entrepreneurial activities that are illegal yet remain legitimate (Webb et al., 2009). As an example of informal economy activities, entrepreneurs can produce legal goods and services while skirting trademark laws, tax regulations, labor laws, or other formal institutional prescriptions. Various institutional centers each prescribe rules that govern economic activity, and entrepreneurs can leverage strategies to respond to the challenges and incentives imposed by those rules. As the jurisdictions of multiple institutional centers overlap, each center can impose prescriptions that are aligned with its own specific objectives but that conflict with those objectives and, therefore, prescriptions of other institutional centers (Webb, Bruton, Tihanyi, \& Ireland, 2013). Conflict across institutional centers creates ambiguities at the institutional level as to what defines legitimate behaviors and outcomes (Fernandez-Kelly, 2006), thereby undermining enforcement and surfacing opportunities in the informal economy for entrepreneurs to exploit. While our findings suggest that some entrepreneurs can exploit network strategies to substitute for a confluence of weak institutions in growing their ventures, extant research also suggests that in other cases entrepreneurs may view the confluence of weak institutions as conferring minimal benefits for operating in the formal economy, motivating and enabling them to pursue opportunities in the informal economy instead. 
We included three types of networks in our study: networks for business resources, advice, and emotional support. Post hoc analysis shows a slightly larger number of ties in the advice networks (mean $=2.21$ ) relative to the business resource networks (mean $=1.74$ ) and emotional support networks (mean $=1.84$ ). Further analysis shows that both advice networks and emotional support networks positively relate to revenue growth $(r=.18, p<.01$ and $r=.12, p<.01$, respectively), but interestingly, business resource networks are not related to growth. Perhaps members of advice networks provide strategic information that is important for the development of the venture while resources networks do not offer a competitive advantage (perhaps the resources provided are necessary for competitive parity). Access to and obtaining resources may be necessary for gaining legitimacy and survival by new ventures. Future research should systematically test the effects of these different networks as well as explore other types of networks (e.g., mentor, political aid, or international networks) and the relational base of these networks (e.g., education, profession, or family) as possible factors associated with network returns. Recently, scholars have suggested that the content and process of social exchange may vary across cultures (Luo, 2011; Shore, Coyle-Shapiro, Chen, \& Tetrick, 2009). For example, the role of social networks may differ in Confucian cultures (Chai \& Rhee, 2010). In this study, the latent culture variable has a negative effect on the revenue growth of the new ventures. Unpacking the effect of culture and the exchange process within social networks in different cultures would contribute to further theoretical refinements in network research as well as provide additional understanding of how entrepreneurs build, maintain, and derive benefits from their networks.

\section{Limitations}

This study has several limitations. First, we relied on slightly different methods to obtain the samples and to verify the data quality in the four countries. While these small differences were dictated by the contexts in which the data were collected, they might introduce some error variance. However, if such error exists, we found no evidence of systematic effects on the results. Second, the sample may be composed of ventures that survived; however, the potential for bias in this study is not severe for the following reasons: The research objective was to compare the financial performance of new ventures rather than examine venture survival. Previous research indicates that financial performance does not predict survival of new firms in all contexts because some financially sound ventures are discontinued while other financially distressed ventures survive longer. This conclusion is particularly applicable to firms in emerging economies (Lyles, Saxton, \& Watson, 2004). In addition, we control for firm age, which has a negative effect on revenue growth (Table 3, models 3-6). We checked firm age distribution, and found that it is not skewed toward older firms. This outcome indirectly indicates that the sample does not suffer from survivor bias. Third, we compared new ventures in terms of revenue growth, which is not the only indicator for entrepreneurial success. Use of other performance indicators, such as employment growth or product development, might produce different outcomes.

\section{Conclusion}

By extending the newly emerging literature on institutional polycentrism, this study contributes to institutional theory, comparative entrepreneurship research, and social network theory. Of particular importance are the contributions to knowledge of entrepreneurship in polycentric institutional orders. To the extent that new venture creation and development is important to the economic development in countries globally, the present study provides a contribution to both theory and practice in the field of entrepreneurship. Social networks, as sources of business resources, advice, and emotional support, are especially important when the confluence of multiple weak and inefficient institutions creates an adverse institutional order for entrepreneurs. This work is interdisciplinary and has important implications for research on the effects of polycentric institutions, and on the effects of networks vis-à-vis the success of new ventures.

\section{REFERENCES}

Acemoglu, D., Johnson, S., \& Robinson, J. 2005. Institutions as a fundamental cause of long-run growth. In P. Aghion \& S. Durlauf (Eds.), Handbook of economic growth, vol. 1: 386-472. New York: Elsevier.

Aidis, R., Estrin, E., \& Mickiewicz, T. 2008. Institutions and entrepreneurship development in Russia: A comparative perspective. Journal of Business Venturing, 23: 656-672. 
Aldrich, H., Reese, P., \& Dubini, P. 1989. Women on the verge of a breakthrough: Networking among entrepreneurs in the United States and Italy. Entrepreneurship and Regional Development, 1: 339-356.

Aldrich, H., \& Ruef, M. 2006. Organizations evolving. London: Sage.

Aligica, P., \& Tarko, V. 2012. Polycentricity: From Polanyi to Ostrom, and beyond. Governance: An International Journal of Policy, Administration, and Institutions, 25: 237-262.

Amable, B. 2003. The diversity of modern capitalism. Oxford, UK: Oxford University Press.

Aoki, M. 1994. The contingent governance of teams: Analysis of institutional complementarity. International Economic Review, 35: 657-676.

Ardagna, S., \& Lusardi, A. 2010. Explaining international differences in entrepreneurship: The role of individual characteristics and regulatory constraints. In J. Lerner \& A. Schoar (Eds.), International differences in entrepreneurship: 17-40. Chicago: University of Chicago Press.

Batjargal, B. 2000. Effects of networks on entrepreneurial performance in a transition economy: The case of Russia. In P. Reynolds, E. Autio, C. Brush, W. Bygrave, S. Manigart, H. Sapienza, \& K. Shaver (Eds.), Frontiers of entrepreneurship research 2000: 97110. Babson Park, MA: Babson College Press.

Batjargal, B. 2003a. Social capital and entrepreneurial performance in Russia: A longitudinal study. Organization Studies, 24: 535-556.

Batjargal, B. 2003b. Internet entrepreneurship in an emerging market: Networks and performance of Internet startups. In Nagao, D. H. (Ed.), Academy of Management best paper proceedings (CD), ISSN 1543-8643.

Batjargal, B. 2005. Entrepreneurial versatility, resources and firm performance in Russia: A panel study. International Journal of Entrepreneurship and Innovation Management Special Issue, 5: 284-297.

Batjargal, B. 2006. The dynamics of entrepreneurs' networks in a transition economy: The case of Russia. Entrepreneurship and Regional Development, 18: 305-320.

Batjargal, B. 2007a. Internet entrepreneurship: Social capital, human capital, and performance of internet ventures in China. Research Policy, 36: 605-618.

Batjargal, B. 2007b. Network triads: Transitivity, referral, and venture capital decisions in China and Russia. Journal of International Business Studies, 38: 9981012.
Batjargal, B. 2007c. Comparative social capital: Networks of entrepreneurs and venture capitalists in China and Russia. Management and Organization Review, 3: 397-419.

Batjargal, B. 2010a. The effects of network's structural holes: Polycentric institutions, product portfolio, and new venture growth in China and Russia. Strategic Entrepreneurship Journal, 4: 146-163.

Batjargal, B. 2010b. Network dynamics and venture performance in China: A longitudinal study. Entrepreneurship and Regional Development, 22: 139-153.

Batjargal, B., Hitt, M., Webb, J., Arregle, J. L., \& Miller, T. 2009. Women and men entrepreneurs' social networks and new venture performance across cultures. In Solomon, G. (Ed.), Academy of Management best paper proceedings.

Batjargal, B., \& Liu, M. 2004. Entrepreneur's access to private equity in China: The role of social capital. Organization Science, 15: 159-172.

Baum, J., Locke, E., \& Smith, K. 2001. A multidimensional model of venture growth. Academy of Management Journal, 44: 292-303.

Baumol, W. 1990. Entrepreneurship: Productive, unproductive, and destructive. Journal of Political Economy, 98: 893-921.

Baumol, W., \& Strom, C. 2007. Entrepreneurship and economic growth. Strategic Entrepreneurship Journal, 1: 233-237.

Bjornskov, C., \& Foss, N. 2008. Economic freedom and entrepreneurial activity: Some cross-country evidence. Public Choice, 134: 307-328.

Boettke, P., \& Coyne, C. 2009. Context matters: Institutions and entrepreneurship. Foundations and Trends in Entrepreneurship, 5(3): 135-209.

Boettke, P., Coyne, C., \& Leeson, P. 2008. Entrepreneurship or entremanureship? Digging through Romania's institutional environment for transition lessons. In B. Powell (Ed.), Making poor nations rich entrepreneurship and the process of economic development: 223-249. Palo Alto, CA: Stanford University Press.

Brass, D., Galaskiewicz, J., Greve, H., \& Tsai, W. 2004. Taking stock of networks and organizations: A multilevel perspective. Academy of Management Journal, 47: 795-817.

Brush, C., \& Vanderwerf, P. 1992. A comparison of methods and sources for obtaining estimates of new venture performance. Journal of Business Venturing, 7: 157-170. 
Burt, R. 1992. Structural holes: The social structure of competition. Cambridge, MA: Harvard University Press.

Busenitz, L., Gomez, C., \& Spencer, J. 2000. Country institutional profiles: Unlocking entrepreneurial phenomena. Academy of Management Journal, 43: 994-1003.

Carsrud, A., Gaglio, C., \& Olm, K. 1987. Entrepreneursmentors, networks, and successful new venture development: An exploratory study. American Journal of Small Business, 12(2): 13-18.

Castilla, E., Hwang, H., Granovetter, E., \& Granovetter, M. 2000. Social networks in Silicon Valley. In C. Lee, W. Miller, R. Rowen, \& M. Hancock (Eds.), The Silicon Valley edge: A habitat for innovation and entrepreneurship: 218-247. Stanford, CA: Stanford University Press.

Chai, S. K., \& Rhee, M. 2010. Confucian capitalism and the paradox of closure and structural holes in East Asian firms. Management and Organization Review, 6: 5-29.

Chen, C. C., Chen, X. P., \& Huang, S. 2013. Chinese guanxi: An integrative review and future research directions. Management and Organization Review, 9: 167-207.

Chin, W. 2010. How to write up and report PLS analysis. In V. Espositi Vinzi, W. W. Chin, J. Henseler, \& H. Wang (Eds.), Handbook of partial least squares: 655-690. Berlin: Springer.

Cook, R. 1979. Influential observations in linear regression. Journal of the American Statistical Association, 74: 169-174.

Crouch, C. 2005. Capitalist diversity and change: Recombinant governance and institutional entrepreneurs. Oxford, UK: Oxford University Press.

Cumming, D., Sapienza, H., Siegel, D., \& Wright, M. 2009. International entrepreneurship: Managerial and policy implications. Strategic Entrepreneurship Journal, 3: 283-296.

Deeg, R. 2005. Path dependency, institutional complementarity, and change in national business systems. In G. Morgan, R. Whitley, \& E. Moen (Eds.), Changing capitalisms? Internationalization, institutional change, and systems of economic organization: 21-52. Oxford, UK: Oxford University Press.

Delmas, M., \& Toffel, M. 2008. Organizational responses to environmental demands: Opening the black box. Strategic Management Journal, 29: 1027-1055.

Desai, M., Gompers, M., \& Lerner, J. 2005. Institutions, capital constraints, and entrepreneurial firm $d y$ - namics: Evidence from Europe. NBER working paper \#10165, Cambridge, MA.

Djankov, S., La Porta, R., Lopez de Silanes, F., \& Shleifer, A. 2002. The regulation of entry. Quarterly Journal of Economics, 117: 1-37.

Djankov, S., Qian, Y., Roland, G., \& Zhuravskaya, E. 2006. Entrepreneurship in China and Russia compared. Journal of European Economic Association, 4: 352-365.

Eisenhardt, K., \& Schoonhoven, C. 1996. Resource-based view of strategic alliance formation: Strategic and social effects in entrepreneurial firms. Organization Science, 7: 136-150.

Esposito Vinzi, V., Chin, W., Henseler, J., \& Wang, H. 2010. Perspectives on partial least squares. In V. Espositi Vinzi, W. W. Chin, J. Henseler, \& H. Wang (Eds.), Handbook of partial least squares: 1-22. Berlin: Springer.

Estrin, S., \& Prevezer, M. 2011. The role of informal institutions in corporate governance: Brazil, Russia, India, and China compared. Asia Pacific Journal of Management, 28: 41-67.

Feldmann, M. 2007. The origins of varieties of capitalism: Lessons from post-socialist transition in Estonia and Slovenia. In B. Hancke, M. Rhodes, \& M. Thatcher (Eds.), Beyond varieties of capitalism, conflict, contradictions, and complementarities in the European economy. Oxford, UK: Oxford University Press.

Fernandez-Kelly, P. 2006. Introduction. In P. FernandezKelly \& J. Shefner (Eds.), Out of the shadows: Political action and the informal economy in Latin America: 1-22. University Park: Pennsylvania State University Press.

Fogel, K., Hawk, A., Morck, R., \& Yeung, B. 2006. Institutional obstacles to entrepreneurship. In M. Casson, B. Yeung, A. Basu, \& N. Wadeson (Eds.), The Oxford handbook of entrepreneurship: 540-579. Oxford, UK: Oxford University Press.

Frye, T. 2000. Brokers and bureaucrats: Building market institutions in Russia. Ann Arbor: University of Michigan Press.

Frye, T., \& Shleifer, A. 1997. The invisible hand and the grabbing hand. American Economic Review Papers and Proceedings, 87: 354-358.

Granovetter, M. 1973. The strength of weak ties. American Journal of Sociology, 78: 1360-1380.

Granovetter, M. 1995. The economic sociology of firms and entrepreneurs. In A. Portes (Ed.), The economic sociology of immigration: 128-165. New York: Sage. 
Green, N. 2007. Functional polycentricity: A formal definition in terms of social network analysis. Urban Studies, 44: 2077-2103.

Greenwood, R., Raynard, M., Kodeih, F., Micelotta, E., \& Lounsbury, M. 2011. Institutional complexity and organizational responses. In J. P. Walsh \& A. P. Brief (Eds.), Academy of Management annals, vol. 5: 317-371. Essex, UK: Routledge.

Greif, A. 2006. Institutions and the path to modern economy: Lessons from medieval trade. Cambridge, UK: Cambridge University Press.

Greif, A., \& Tabellini, G. 2010. Cultural and institutional bifurcation: China and Europe compared. American Economic Review: Papers and Proceedings, 100: $1-10$.

Guseva, A., \& Rona-Tas, A. 2001. Uncertainty, risk, and trust: Russian and American credit card markets compared. American Sociological Review, 66: 623646.

Gwartney, J., Lawson, R., \& Block, W. 1996. Economic freedom of the world: 1975-1995. Vancouver: Fraser Institute.

Hall, P., \& Soskice, D. 2001. Varieties of capitalism: The institutional foundations of comparative advantage. Oxford, UK: Oxford University Press.

Hall, P., \& Thelen, K. 2009. Institutional change in varieties of capitalism. Socio-Economic Review, 7: $7-34$.

Hancke, B. 2010. Varieties of capitalism and business. In D. Coen, W. Grant, \& G. Wilson (Eds.), The Oxford handbook of business and government: 123-147. Oxford, UK: Oxford University Press.

Hayek, F. A. 1973. Law, legislation, and liberty, rules and order, vol. 1. Chicago: University of Chicago Press.

Heberer, T. 2003. Private entrepreneurs in China and Vietnam: Social and political functioning of strategic groups. Leiden, The Netherlands, and Boston: Brill.

Heckman, J. 1979. Sample selection bias as a specification error. Econometrica, 47: 153-161.

Helmke, G., \& Levitsky, S. 2004. Informal institutions and comparative politics: A research agenda. Perspectives on Politics, 2: 725-740.

Henseler, J., Ringle, C. M., \& Sinkovics, R. R. 2009. The use of partial least squares path modeling in international marketing. Advances in International Marketing, 20: 277-319.

Herrmann, A. 2008. Rethinking the link between labor market flexibility and corporate competitiveness: A critique of the institutionalist literature. Socio-Economic Review, 6: 637-669.

Hitt, M., Ahlstrom, D., Dacin, T., Levitas, E., \& Svobodina, L. 2004. The institutional effects on strategic alliance partner selection in transition economies: China versus Russia. Organization Science, 15: 173-185.

Hitt, M., Beamish, P., Jackson, S., \& Mathieu, J. 2007. Building theoretical and empirical bridges across levels: Multilevel research in management. Academy of Management Journal, 50: 1385-1399.

Hitt, M., Bierman, L., Uhlenbruck, K., \& Shimizu, K. 2006. The importance of resources in the internationalization of professional service firms: The good, the bad, and the ugly. Academy of Management Journal, 49: 1137-1157.

Holmes, M., Miller, T., Hitt, M., \& Salmador, P. 2013. The interrelationships among informal institutions, formal institutions, and inward foreign direct investment. Journal of Management, 39: 531-566.

House, R., Hanges, P., Javidan, M., Dorfman, P., \& Gupta, P. (Eds.). 2004. Culture, leadership and organizations: The Globe study of 62 societies. Thousand Oaks, CA: Sage.

Hulland, J. 1999. Use of partial least squares (PLS) in strategic management research: A review of four recent studies. Strategic Management Journal, 20: 195-204.

Hwang, H., \& Powell, W. 2005. Institutions and entrepreneurship. In S. Alvarez, R. Agarwal, \& O. Sorenson (Eds.), Handbook of entrepreneurship research: Disciplinary perspectives: 201-232. New York: Springer.

James, L. R., Demaree, R., \& Wolf, G. 1984. Estimating within-group inter-rater reliability with and without response bias. Journal of Applied Psychology, 69: 85-98.

Keats, B., \& Hitt, M. 1988. A causal model of linkages among environmental dimensions, macro organizational characteristics, and performance. Academy of Management Journal, 31: 570-598.

Kharkhordin, O., \& Gerber, T. 1994. Russian directors' business ethic: A study of industrial enterprises in St. Petersburg, 1993. Europe-Asia Studies, 46: 1075-1107.

Kim, P., \& Aldrich, H. 2005. Social capital and entrepreneurship. Foundations and Trends in Entrepreneurship, 1(2): 55-104.

Kogut, B., \& Ragin, C. 2006. Exploring complexity when diversity is limited: Institutional complementarity in 
theories of rule of law and national systems revisited. European Management Review, 3: 44-59.

Krueger, N., \& Dickson, P. R. 1994. How believing in ourselves increases risk taking: Perceived self-efficacy and opportunity recognition. Decision Sciences, 25: 385-400.

Langowitz, N., \& Minniti, M. 2007. The entrepreneurial propensity of women. Entrepreneurship: Theory and Practice, 31: 341-364.

Ledeneva, A. 1998. Russia's economy of favors: Blat, networking, and informal exchange. Cambridge, UK: Cambridge University Press.

LeLarge, C., Sraer, D., \& Thesmar, D. 2010. Entrepreneurship and credit constraints: Evidence from a French loan guarantee program. In J. Lerner \& A. Schoar (Eds.), International differences in entrepreneurship: 243-274. Chicago, IL: University of Chicago Press.

Lerner, J., \& Schoar, A. (Eds.). 2010. International differences in entrepreneurship. Chicago: University of Chicago Press.

Li, H., Meng, L., Wang, Q., \& Zhou, L. 2008. Political connections, financing, and firm performance: Evidence from Chinese private firms. Journal of Development Economics, 87: 283-299.

Little, R., \& Rubin, B. 2002. Statistical analysis with missing data (2nd ed.). New York: Wiley.

Luo, J.-D.. 2011. Guanxi revisited: An exploratory study of familiar ties in a Chinese workplace. Management and Organization Review, 7: 329-351.

Luo, Y., Huang, Y., \& Wang, S. L. 2012. Guanxi and organizational performance: A meta-analysis. Management and Organization Review, 8: 139-172.

Lyles, M., Saxton, T., \& Watson, K. 2004. Venture survival in a transitional economy. Journal of Management, 30: 351-375.

Malesky, E., \& Taussig, M. 2009. Where is credit due? Legal institutions, connections, and the efficiency of bank lending in Vietnam. Journal of Law, Economics and Organization, 25: 535-578.

Marsden, P. 1982. Brokerage behavior in restricted exchange networks. In P. Marsden \& N. Lin (Eds.), Social structure and network analysis: 201-218. Beverly Hills, CA: Sage.

Marsden, P. 1990. Network data and measurement. In W. R. Scott \& J. Blake (Eds.), Annual review of sociology, vol. 16: 435-463. Palo Alto, CA: Annual Reviews.

McGinnis, M. 2011. An introduction to IAD and the language of the Ostrom Workshop: A simple guide to a complex framework. Policy Studies Journal, 39: 169-183.

McMillan, J., \& Woodruff, C. 1999. Interfirm relationships and informal credit in Vietnam. Quarterly Journal of Economics, 114: 1285-1320.

McPherson, M., Smith-Lovin, L., \& Brashears, M. 2006. Social isolation in America: Changes in core discussion networks over two decades. American Sociological Review, 71: 353-375.

Nee, V. 2005. Organizational dynamics of institutional change: Politicized capitalism in China. In V. Nee \& R. Swedberg (Eds.), The economic sociology of capitalism: 53-74. Princeton, NJ: Princeton University Press.

North, D. C. 1990. Institutions, institutional change, and economic performance. Cambridge, UK: Cambridge University Press.

North, D. C. 2005. Understanding the process of economic change. Princeton, NJ: Princeton University Press.

North, D. C., \& Shirley, M. 2008. Economics, political institutions, and financial markets. In S. Haber, D. C. North, \& B. Weingast (Eds.), Political institutions and financial development: 287-296. Stanford, CA: Stanford University Press.

Ostrom, E. 1986. An agenda for the study of institutions. Public Choice, 48: 3-25.

Ostrom, E. 1990. Governing the commons: The evolution of institutions for collective action. Cambridge, UK: Cambridge University Press.

Ostrom, E. 2005a. Understanding institutional diversity. Princeton, NJ: Princeton University Press.

Ostrom, E. 2005b. Unlocking public entrepreneurship and public economies. Discussion paper, World Institute for Development Economics Research, United Nations University, Helsinki.

Ostrom, E. 2010. Beyond markets and states: Polycentric governance of complex economic systems. American Economic Review, 100: 641-672.

Ostrom, E. 2011. Background on the institutional analysis and development framework. Policy Studies Journal, 39: 7-27.

Ostrom, E., \& Ahn, T. K. 2009. The meaning of social capital and its links to collective action. In G. T. Svendsen \& G. L. Svendsen (Eds.), Handbook of social capital: The troika of sociology, political science, and economics: 17-35. Northampton, UK: Elgar. 
Ostrom, E., \& Basurto, X. 2011. Crafting analytical tools to study institutional change. Journal of Institutional Economics, 7: 317-343.

Ostrom, E., Schroeder, L., \& Wynne, L. 1993. Institutional incentives and sustainable development: Infrastructure policies in perspective. Boulder, CO: West View.

Ostrom, E., \& Walker, J. 2000. Neither markets nor states: Linking transformation processes in collective action arenas. In M. McGinnis (Ed.), Polycentric games and institutions: 427-471. Ann Arbor: University of Michigan Press.

Ostrom, V. 1999a. Polycentricity (part 1). In M. McGinnis (Ed.), Polycentricity and local public economies: 52-74. Ann Arbor: University of Michigan Press.

Ostrom, V. 1999b. Polycentricity (part 2). In M. McGinnis (Ed.), Polycentricity and local public economies: 119-138. Ann Arbor: University of Michigan Press.

Ovaska, T., \& Sobel, R. 2005. Entrepreneurship in postsocialist economies. Journal of Private Enterprise, 21(1): 8-28.

Owen-Smith, J., \& Powell, W. 2008. Networks and institutions. In R. Greenwood, C. Oliver, R. Suddaby, \& K. Sahlin-Andersson (Eds.), Handbook of organizational institutionalism: 594-621. Thousand Oaks, CA: Sage.

Pache, A., \& Santos, F. 2010. When worlds collide: The internal dynamics of organizational responses to conflicting institutional demands. Academy of Management Review, 35: 455-476.

Polanyi, M. 1951. The logic of liberty. Chicago: University of Chicago Press.

Ringle, C. M., Wende, S., \& Will, A. 2005. SmartPLS 2.0. Hamburg: SmartPLS.

Schneider, B., \& Karcher, S. 2010. Complementarities and continuities in the political economy of labor markets in Latin America. Socio-Economic Review, 8: $623-651$.

Sedaitis, J. 1998. The alliances of spin-offs versus startups: Social ties in the genesis of post-Soviet alliances. Organization Science, 9: 368-381.

Seo, M., \& Creed, D. 2002. Institutional contradictions, praxis, and institutional change: A dialectical perspective. Academy of Management Review, 27: 222-247.

Shamir, B., Zakay, E., \& Popper, M. 1998. Correlates of charismatic leader behavior in military units: Subordinates' attitudes, unit characteristics, and superiors' appraisals of leader performance. Academy of Management Journal, 41: 387-409.
Shleifer, A. 2005. A normal country: Russia after communism. Cambridge, MA: Harvard University Press.

Shore, L. M., Coyle-Shapiro, J., Chen, X., \& Tetrick, L. 2009. Social exchange in work settings: Content, mixed, and process models. Management and Organization Review, 5: 289-302.

Sobel, R., Clark, J., \& Lee, D. 2007. Freedom, barriers to entry, entrepreneurship, and economic progress. Review of Austrian Economics, 20: 221-236.

Sobel, R., \& Coyne, C. 2011. Cointegrating institutions: The time-series properties of country institutional measures. Journal of Law and Economics, 54: 111134.

Spicer, A., \& Pyle, W. 2002. Institutions and the vicious circle of distrust in the Russian household deposit market, 1992-1999. Advances in Strategic Management, 19: 371-396.

Stam, W., \& Elfring, T. 2008. Entrepreneurial orientation and new venture performance: The moderating role of intra- and extra-industry social capital. Academy of Management Journal, 51: 97-111.

Stuart, T., \& Sorenson, O. 2007. Strategic networks and entrepreneurial ventures. Strategic Entrepreneurship Journal, 1: 211-227.

Tonoyan, V., Strohmeyer, R., Habib, M., \& Perlitz, M. 2010. Corruption and entrepreneurship: How formal and informal institutions shape small firm behavior in transition and mature market economies. Entrepreneurship: Theory and Practice, 34: 803-831.

Tsai, K. 2002. Back-alley banking: Private entrepreneurs in China. Ithaca, NY: Cornell University Press.

Tsai, K. 2007. Capitalism without democracy: The private sector in contemporary China. Ithaca, NY: Cornell University Press.

Tzeng, C., Beamish, P., \& Chen, S. 2011. Institutions and entrepreneurship development: High-technology indigenous firms in China and Taiwan. Asia Pacific Journal of Management, 28: 453-481.

Uzzi, B. 1997. Social structure and competition in interfirm networks: The paradox of embeddedness. Administrative Science Quarterly, 42: 35-67.

Volkov, V. 2002. Violent entrepreneurs: The use of force in the making of Russian capitalism. Ithaca, NY: Cornell University Press.

Webb, J. W., Bruton, G. D., Tihanyi, L., \& Ireland, D. 2013. Research on entrepreneurship in the informal economy: Framing a research agenda. Journal of Business Venturing, 28: 598-614. 
Webb, J. W., Kistruck, G. M., Ireland, R. D., \& Ketchen, D. J. 2010. The entrepreneurship process in base of the pyramid markets: The case of multinational enterprise/nongovernmental organization alliances. Entrepreneurship: Theory and Practice, 34: 555581.

Webb, J. W., Tihanyi, L., Ireland, R. D., \& Sirmon, D. G. 2009. You say illegal, I say legitimate: Entrepreneurship in the informal economy. Academy of Management Review, 34: 492-510.

Wilson, R., \& Herzberg, R. 2000. Negative decision powers and institutional equilibrium: Experiments on blocking coalitions. In M. McGinnis (Ed.), Polycentric games and institutions: 184-201. Ann Arbor: University of Michigan Press.

World Bank. 2010. Doing business 2011: Making a difference for entrepreneurs. Washington DC: World Bank.

Wulfgramm, M. 2011. Can activating labor market policy offset the detrimental life satisfaction effect of unemployment? Socio-Economic Review, 9: 477-501.

Xiao, Z. X., \& Tsui, A. S. 2007. When brokers may not work: The culture contingency of social capital in Chinese high-tech firms. Administrative Science Quarterly, 52: 1-31.

Xin, K., \& Pearce, J. 1996. Guanxi: Connections as substitutes for formal institutional support. Academy of Management Journal, 39: 1641-1658.

$\mathrm{Xu}, \mathrm{C} .2011$. The fundamental institutions of China's reforms and development. Journal of Economic Literature, 49: 1076-1151.

Zahra, S. A. 1996. Technology, strategy, and new venture performance: A study of corporate-sponsored and independent biotechnology ventures. Journal of Business Venturing, 11: 289-321.

\section{APPENDIX A}

\section{Institutional Variables by Data Source ${ }^{a}$}

Freedom House: Civil liberties index, political rights International Country Risk Guide: Corruption.

Index of Economic Freedom (Gwartney, Lawson, \& Block, 1996): Contract and property rights, fiscal burden, foreign investment restrictions, government control over wages and prices, government intervention in banking, government restrictions on industry, informal market, monetary policy, regulatory burden, trade policy.

\footnotetext{
${ }^{\text {a }}$ Please see Holmes et al. (2013) for more information on institutional variables, their transformations, and definitions.
}

POLCON: Executive political restrictions, political constraints.

Political Risk Services: Government budget balance, capital investment, change in real wages, credit transfers, exchange rate, debt service cost, industry workforce, inflation rate, liabilities, liquidity, money supply, net reserves, nominal GDP, size of population, services workforce, trade balance, total foreign debt, unemployment rate, unionized workforce.

World Bank's World Development Indicators: Value of stocks traded.

\section{APPENDIX B}

Institutional Measurements: Results of Factor Analysis ${ }^{a}$

\begin{tabular}{|c|c|c|}
\hline Factor & Item & $\begin{array}{l}\text { Factor } \\
\text { Loading }\end{array}$ \\
\hline \multirow[t]{4}{*}{ Political democracy } & Political constraints & 0.96 \\
\hline & Political rights & -0.87 \\
\hline & Civil liberties & -0.76 \\
\hline & Executive political restrictions & 0.68 \\
\hline \multirow[t]{7}{*}{ Regulatory control } & Regulatory burden & 0.80 \\
\hline & Contract and property rights & 0.79 \\
\hline & Trade policy & 0.77 \\
\hline & Informal markets & 0.77 \\
\hline & $\begin{array}{l}\text { Government intervention in } \\
\text { banking }\end{array}$ & 0.77 \\
\hline & $\begin{array}{l}\text { Foreign investment } \\
\text { restrictions }\end{array}$ & 0.75 \\
\hline & Monetary policy & 0.58 \\
\hline \multirow[t]{6}{*}{ Capital availability } & Money supply & 0.96 \\
\hline & Capital investments & 0.94 \\
\hline & Total foreign debt & 0.93 \\
\hline & Nominal GDP & 0.89 \\
\hline & Budget balance & -0.73 \\
\hline & Net reserves & 0.71 \\
\hline \multirow[t]{4}{*}{ Market liquidity } & Liabilities & 0.78 \\
\hline & Liquidity & -0.72 \\
\hline & Exchange rate & 0.64 \\
\hline & $\begin{array}{l}\text { Total proportion of variance } \\
\text { explained }\end{array}$ & 70.8 \\
\hline
\end{tabular}

${ }^{\text {a }}$ Please see Holmes et al. (2013) for a complete exploratory factor analysis with all factor loadings.

\section{APPENDIX C}

\section{Industry Sales Data Sources}

\section{Chinese Industry Data}

(1) The sales data for retail trade, wholesale trade, service, the IT industry, biotechnology, and light manufacturing for 2000-04 were collected from the following sources: the China Statistical Yearbook (1999-2004); Zhonghua Renmin Gongheguo Guojia Tongji Ju (National 
Bureau of Statistics of the People's Republic of China). http://www.stats.gov.cn/english/statisticaldata/yearlydata. Accessed April 20, 2010.

(2) The sales data for the software industry for 2000-04 were collected from the following sources: Software and Information Service Industries are Beijing's Advantageous Industries, Beijingshi Kexue Jishu Weiyuanhui (Beijing Municipal Science \& Technology Commission). http://www.bjkw.gov.cn/htm/ztrd_zxgz/zxgz090508/nig uangnan2.html. Accessed May 5, 2010.

\section{Russian Industry Data}

(1) The sales data for retail and wholesale trade for 2000-04 were collected from the following sources: Torgovlya $v$ Rossii [Trade in Russia], 2005(1): 1-11; Vorposy Statistiki [Problems of Statistics], 2006(3): 66-77; 2006(5): 87-93; 2006(6): 72-83; 2006(10): 82-83; 2007(1): 83-94; 2007(3): 82-93; 2007(10): 60-71; Federal'naya Sluzhba Gosudarstvennoi Statistiki [Federal State Statistics Service, Russian Federation].

(2) The sales data for the service industry for 2000-04 were collected from the following sources: Statisticheskoe Obozrenie [Current Statistical Survey], 2000(1); 2001(1); 2002(1): 43-45; 2003(1); 2004(1): 64-66; 2005(1): 64-66; Federal'naya Sluzhba Gosudarstvennoi Statistiki.

(3) The sales data for the IT and software industries for 2000-04 were collected from the following sources: Rossiiskii Statisticheskii Ezhegodnik [Russian Statistical Annuals], 2004(1): 555-560; 2005(1); Russia in Figures, 2002(1): 269-285; 2003(1): 267-283; Federal'naya Sluzhba Gosudarstvennoi Statistiki.

(4) The sales data for the biotech industry for 2000-04 were collected from the following sources: Promyshlennost' $v$ Rossii [Industries in Russia], 2005(1); Russia in Figures, 2001(1); Federal'naya Sluzhba Gosudarstvennoi Statistiki.

(5) The sales data for the light manufacturing industry were collected from the following sources: Statisticheskoe Obozrenie, 2002(1): 23-33; 2003(1); 2004(1): 39-50; 2005(1): 39-50; 2005(4); Federal'naya Sluzhba Gosudarstvennoi Statistiki.

\section{French Industry Data}

The sales data were collected from the Eurostat online database on European industries. http://epp.eurostat.ec. europa.eu/portal/page/portal/statistics/search_database. Accessed January 5, 2010.

\section{US Industry Data}

Industry sales data for the United States were gathered from Compustat North America. http://www.compustat. com. Accessed June 1, 2010.

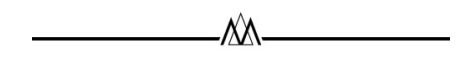

Bat Batjargal (batjarg@fas.harvard.edu) is a research associate at Harvard University's Davis Center and visiting professor at the Guanghua School of Management of Peking University. He earned his Ph.D. from the University of Oxford. His research interests focus on institutional polycentrism and diversity, social capital and networks, new firm growth, and venture capital in emerging economies.

Michael A. Hitt (mhitt@mays.tamu.edu) is a University Distinguished Professor and holds the Joe B. Foster Chair in Business Leadership in the Mays Business School at Texas A\&M University. He received his Ph.D. from the University of Colorado. His research interests include international strategy, particularly the effects of institutions on firm strategies and entrepreneurial actions, the importance of resource orchestration for achieving a competitive advantage, and family business strategies.

Anne S. Tsui (anne.tsui@asu.edu) is the Motorola Professor of International Management Emerita, Arizona State University, and Distinguished Visiting Professor of Fudan University, Peking University, and Shanghai Jiao Tong University. She received her Ph.D. from the University of California, Los Angeles. Her research interests include managerial effectiveness, human resources effectiveness, demographic diversity, employment relationship, executive leadership, organizational culture, and Chinese management.

Jean-Luc Arregle (arregle@em-lyon.com) is professor of strategy and international business at EM Lyon Business School. He received his Ph.D. in strategy at the Institut d'Administration des Entreprises in Aix-en-Provence. His research interests include the roles of institutions in MNEs' international strategy, MNEs' regional strategies (semiglobalization), social capital, and family firms' strategy.

Justin W. Webb (justin.w.webb@okstate.edu) is an assistant professor of entrepreneurship in the School of Entrepreneurship at Oklahoma State University. He received his Ph.D. in management from the Mays Business School at Texas A\&M University. His research examines institutional and individual-level influences on the entrepreneurship process, with particular emphasis on entrepreneurship occurring within informal and base-ofthe-pyramid markets.

Toyah L. Miller (milleto2@indiana.edu) is an assistant professor of strategic management and entrepreneurship at the Kelley School of Business, Indiana University. She received her Ph.D. from Texas A\&M University. Her research interests include cognitive perspectives on entrepreneurship (including social entrepreneurship), and international and learning perspectives on innovation and change in organizations. 